\title{
Biomarkers, stable carbon isotope, and trace element distribution of source rocks in the Orange Basin, South Africa: implications for paleoenvironmental reconstruction, provenance, and tectonic setting
}

\author{
Nura Abdulmumini Yelwa ${ }^{1,2} \cdot$ Khairul Azlan Mustapha $^{1}$ (D) Mimonitu Opuwari ${ }^{3} \cdot$ Azharuddin Abd Aziz $^{4}$
}

Received: 14 August 2021 / Accepted: 26 September 2021 / Published online: 27 November 2021

(c) The Author(s) 2021

\begin{abstract}
Aptian to Campanian sediments from the Western offshore to Central Orange Basin were studied by integrating molecular geochemistry, inorganic and isotopic studies to recognize their geochemical characteristics via the reconstruction of the Orange basin's paleoweathering, paleosalinity, paleovegetation, paleoclimate, and tectonic records. Molecular analyses of both aliphatic and aromatic compounds reveal an input dominantly from a marine source. The source rocks accumulated in a reduced, anoxic, saline water column. Based on various biomarker proxies and vitrinite reflectance data, some samples are thermally mature to produce petroleum, while others are not. According to the V/Ni ratio, samples from the Orange Basin in South Africa are mainly anoxic, with only a few samples ranging from suboxic to anoxic. This is congruent with biomarker and isotope analyses that further indicate the presence of marine-derived source rocks with some terrestrial remains generating hydrocarbons. The investigated sediments are made up of intermediate igneous rocks that have undergone moderate chemical weathering. Geochemical figures on tectonic setting discriminant function diagrams revealed a continental rift of passive margin settings. As a result, the extrapolated crustal processes are directly analogous to the genesis and evolution of the Orange Basin, demonstrating Gondwana's breaking up and the opening of the Atlantic Ocean Margin.
\end{abstract}

Keywords Biomarker $\cdot$ Trace element $\cdot$ Stable isotope $\cdot$ Orange basin $\cdot$ Provenance $\cdot$ Tectonic setting

\section{Introduction}

During the last thirty years, the South African government has been motivated to explore the Orange Basin due to the discovery of valuable petroleum on the southern Atlantic margins (Jungslager 1999; Hartwig et al. 2012; Adekola et al. 2012). The huge Ibhubesi gas reserve off South Africa

Khairul Azlan Mustapha

azlan_0401@um.edu.my; azlan.geo@gmail.com

1 Department of Geology, Faculty of Science, University of Malaya, 50603 Kuala Lumpur, Malaysia

2 Department of Geology, Usmanu Danfodiyo University, P.M.B. 2346, Sokoto, Nigeria

3 Earth Sciences Department, University of the Western Cape, Bellville 7535, South Africa

4 Department of Chemistry Malaysia, Ministry of Science, Technology and Innovation, Jalan Sultan, Petaling Jaya, 46661 Selangor, Malaysia as well as the Kudu gas field in South Namibia are the result of ongoing hydrocarbon prospecting (PASA 2003). There have been some reports on the geochemical attributes of source rocks from the Orange Basin (Jungslager 1999; Van der Spuy 2003). According to Jungslager (1999) and Van der Spuy (2003), the Orange Basin has primarily three source rock intervals.

Organic geochemistry is an important tool for identifying source rocks and classifying crude oils into families both at the beginning and later stages in oil exploration (Peters et al. 2005; Akinlua et al. 2007a, 2007b; Adekola et al. 2012). A thorough geochemical analysis of source rocks can reveal information about the hydrocarbons they produce (Adekola et al. 2012). The composition and long-term preservation of organic matter deposited in the marine domain throughout the Orange Basin is related to deposition system stacking and, as a result, the depositional systems tracts in which it was deposited (Adekola et al. 2012). Most geochemical analyses rely heavily on data obtained from bitumen extraction. This yields biomarkers from both aliphatic and 
aromatic fractions that could be utilized to deduce organic source input, paleoredox condition, maturity, and age determination as well as relating their provenance (Peters et al. 2005). Therefore, the quantity, quality and thermal maturation of source rocks are pivotal in petroleum exploration. In order to answer some questions such as organic matter origin, depositional condition, thermal maturation, type and quality of source rocks, researchers ought to work on many representative samples extending up to the deeper Orange Basin. In characterizing the source rocks, these conventional methods may be related to unconventional approaches such as nuclear magnetic resonance (NMR), Fourier transform infrared spectroscopy (FTIR), and thermogravimetric analysis (TGA).

In petroleum exploration, trace elements are also used to delineate the emergence, depositional environment, thermal maturity of organic matter, as well as pathways of oil movement (Lewan 1984; Akinlua et al. 2015, 2018). Metal concentration ratios $(\mathrm{V} /(\mathrm{V}+\mathrm{Ni}))$ is used to identify organic matters within sediments, such as siliceous versus phosphatic shales (Akinlua et al. 2010). The types of organic matter and depositional environment, according to Lewan (1984), have a significant impact on the amount of trace elements in source rocks. As a result, the trace element content of source rock has become a valuable geochemical tool for evaluating source rock. The concentration of trace elements certifies the source rock type (Barwise 1990). A reliable paleoenvironmental marker, the trace element is not inhibited by maturation and is used to depict depositional age in source sediments as well as likely time to generate hydrocarbons. Cumming et al. (2014) determined the depositional age of source rocks and the timing of petroleum generation in the Uinta Basin using rhenium-osmium geochronology (Re-Os). Some research has been conducted on crude oil and condensates, as well as on the source rock geochemistry of the South African basin (Davies 1997; Jungslager 1999; Vander Spuy et al. 2003; Akinlua et al. 2010) but scarce inorganic geochemical work undertaken on whole rock samples. The study of stable carbon isotopes is used to investigate environmental issues that impact organic matter, like paleoclimatic evolution (Hentschel et al. 2016); provenances (Thornton and McManus 1994).

The integration of organic and inorganic geochemistry provides a multiscale perspective that allows researchers to answer some questions such as origin of organic matter, genetic linkage within the source rocks, deposition, thermal maturity, sediment age, type and quality of source rocks, mineral content, and chemical composition of the vast, unexplored Orange Basin post-rift sequence. In this context, molecular geochemistry, inorganic methods and isotopic studies were integrated to recognize their geochemical characteristics through the reconstruction of the Orange basin's paleovegetation and paleoweathering. This approach could also be adapted to understand certain tectonic elements and prospectivity in other basins in the world. In addition, the characterization of some representative rock samples for elementary analysis resulted in a useful environmental and health implications database.

\section{The geologic setting}

The Orange Basin is an offshore passive continental boundary of Southwest Africa's Atlantic Ocean (Fig. 1; Akinlua et al. 2011; Jungslager 1999) that is bounded to the north by the Kudu Arc and to the south by the Agulhas-Columbine Arc (Fig. 2; Hirsch et al. 2007; Muntingh and Brown 1993). The basin formed in the late Jurassic-Tertiary period (Brown 1995; Gerrard and Smith 1982; Muntingh 1993). It is located between latitudes 31-33.5 S and longitudes 16-17 E, stretching nearly $160,000 \mathrm{~km}^{2}$ extending from the continental shelf toward the deep offshore marine, as shown in Fig. 1 (PASA 2003; Broad et al. 2006).

Orange Basin seems to be larger than the other six (6) basins in South Africa put together (McMillan 2003). Its main source is the Orange River, which empties into the South Atlantic Ocean (Akinlua et al. 2011). Despite the Orange Basin being South Africa's largest offshore basin, less than 40 wells have been drilled, equating to one well per $4000 \mathrm{Km}^{2}$ (Muntingh 1993). An estimated 43,000 km² of deep-water license area extends from Namibia's offshore southwest volcanic passive margin (Paton et al. 2007) spanning from the upper Jurassic to the Holocene (Kuhlmann et al. 2010). Figure 2 illustrates the basin's many onshore provinces, mobile belts, craton, and the Kalahari shield.

Source rock intervals in the Orange Basin are best explained by tectonostratigraphic events. The tectonic stages are as follows: late synrift, early post-rift, and drift succession (Jungslager 1999). These features resemble sedimentary trenches (Akinlua et al. 2010) made of source rock (Van der Spuy et al. 2003).

According to petroleum systems, they are also classified based on individual organic matter content, hydrocarbon type, and spatial distribution. Within the Orange Basin, three (3) most qualitative source rock intervals were discovered. These major source rock intervals are as follows:

i. Hauterivian synrift lacustrine source rocks (Type I)

ii. Pelagic transition sediments from the Barremian to the Lower Aptian (Type II/III) (Jungslager 1999).

iii. Marine source rocks from the Aptian drift stage (112$103 \mathrm{Ma})$

iv. Cenomanian-Turonian Type II drift marine source rocks (Vander Spuy et al. 2003). 


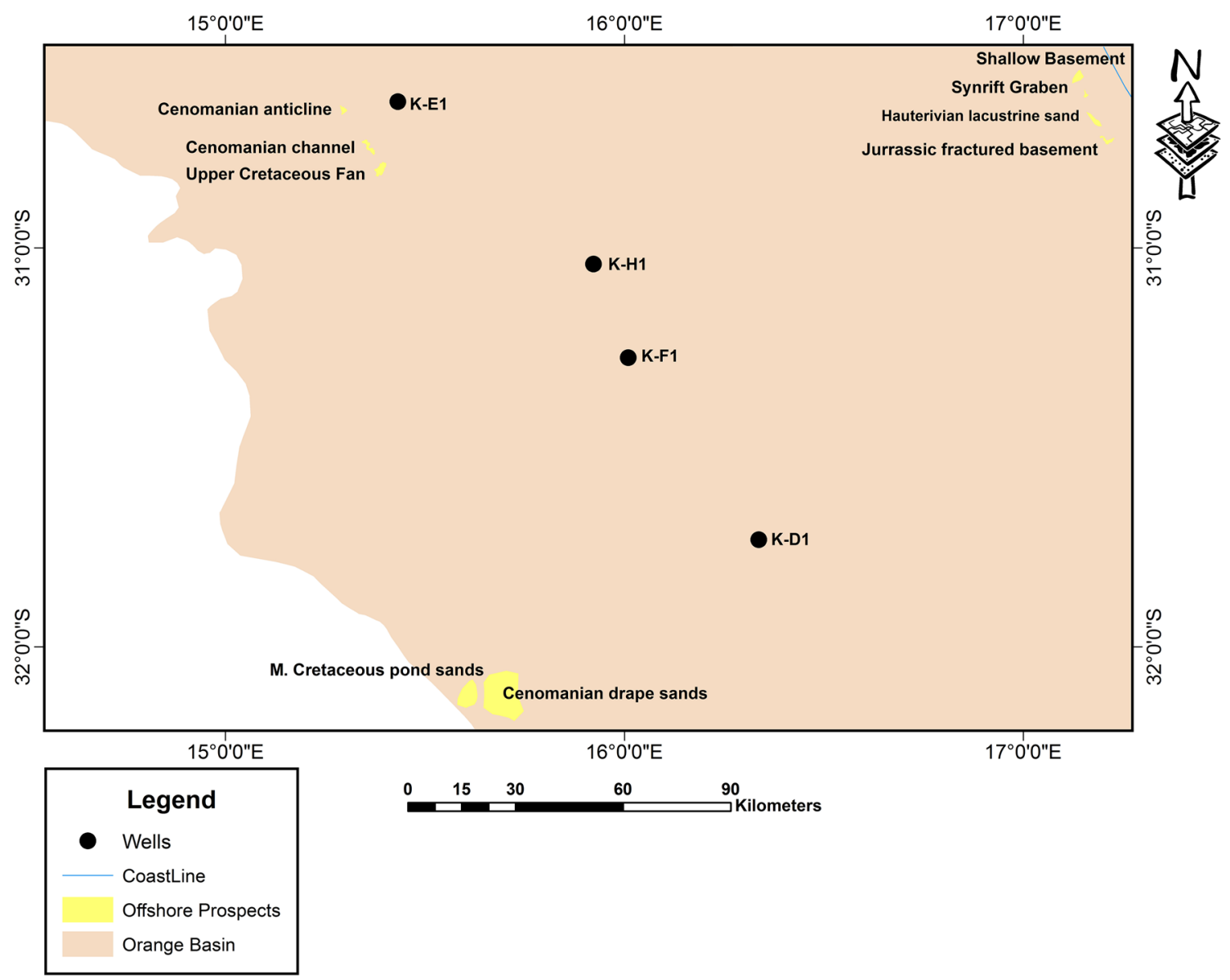

Fig. 1 K-Wells and prospects of the study area, Orange Basin

The Hauterivian synrift source rock is only found in the Orange Basin at the AJ1 well's half-graben (Barton et al. 1993). The source rock aids in the correlation and reconstruction of the environment up to the South American margins (Paton et al. 2007). Age-wise, Barremian rocks are the second category of source rocks, which is found between the transition-drift tectonic stage in the Aptian anoxic environment (Van der Spuy et al. 2003). It penetrates the AKhalf-graben, as evidenced by the AK wells that produce gas. Likewise, the Barremian to Lower Aptian source manifests at OA1 and is oil prone (Jungslager 1999). The source rocks are likely to enrich Namibia's Kudu gas and the Ibhubesi fields (Kuhlmann et al. 2010).

Finally, within the AK1's half-graben, the Turonian drift phase source interval appears, presumably producing gas and oil (Van der Spuy et al. 2003). Fluvial and deltaic sandstones with conglomerate from the Paleozoic Karoo section and underlying basement rocks serve as reservoir rocks in the rifting region. Fluvial sandstones and floodplain sediments are found in the drift stage (Jungslager 1999). The Orange Basin contains a variety of play types, including rift plays, which are lacustrine sandstones that trap hydrocarbons from organic-rich claystone. Another significant play is the synrift sediments with drift plays, which include early Cretaceous aeolian sandstone plays, Albian incised valleys, shallow to deep-water structural sediments, and rolling over anticlines (Vander Spuy et al. 2003).

\section{Sampling and analytic techniques}

Twenty shales were collected from cutting samples of the Orange Basin in four-wells KD-1, KE-1, KF-1, and KH-1 (Fig. 1). The initial geochemical approach began with cleaning, removing oxidized surfaces, followed by crushing and grinding the shale to a fine powder with a pestle and mortar. About 5-10 g of the powdered sample was extracted for $72 \mathrm{~h}$ by using Soxhlet apparatus to evaluate extractable organic matter $(\mathrm{OM})$ concentrates as well as the hydrocarbon content of the examined sediments. In a glass jar, 93 percent dichloromethane was mixed with 7 percent methanol before being poured into an empty solvent bottle and thoroughly shaken. A 250-ml conical flask and Soxhlet extractor apparatus 
Fig. 2 Geologic setting of southwestern Africa (modified after Hirsch et al. 2009). Illustration shows old cratons enclosing mobile belts that gradually grow during the Damara Orogeny

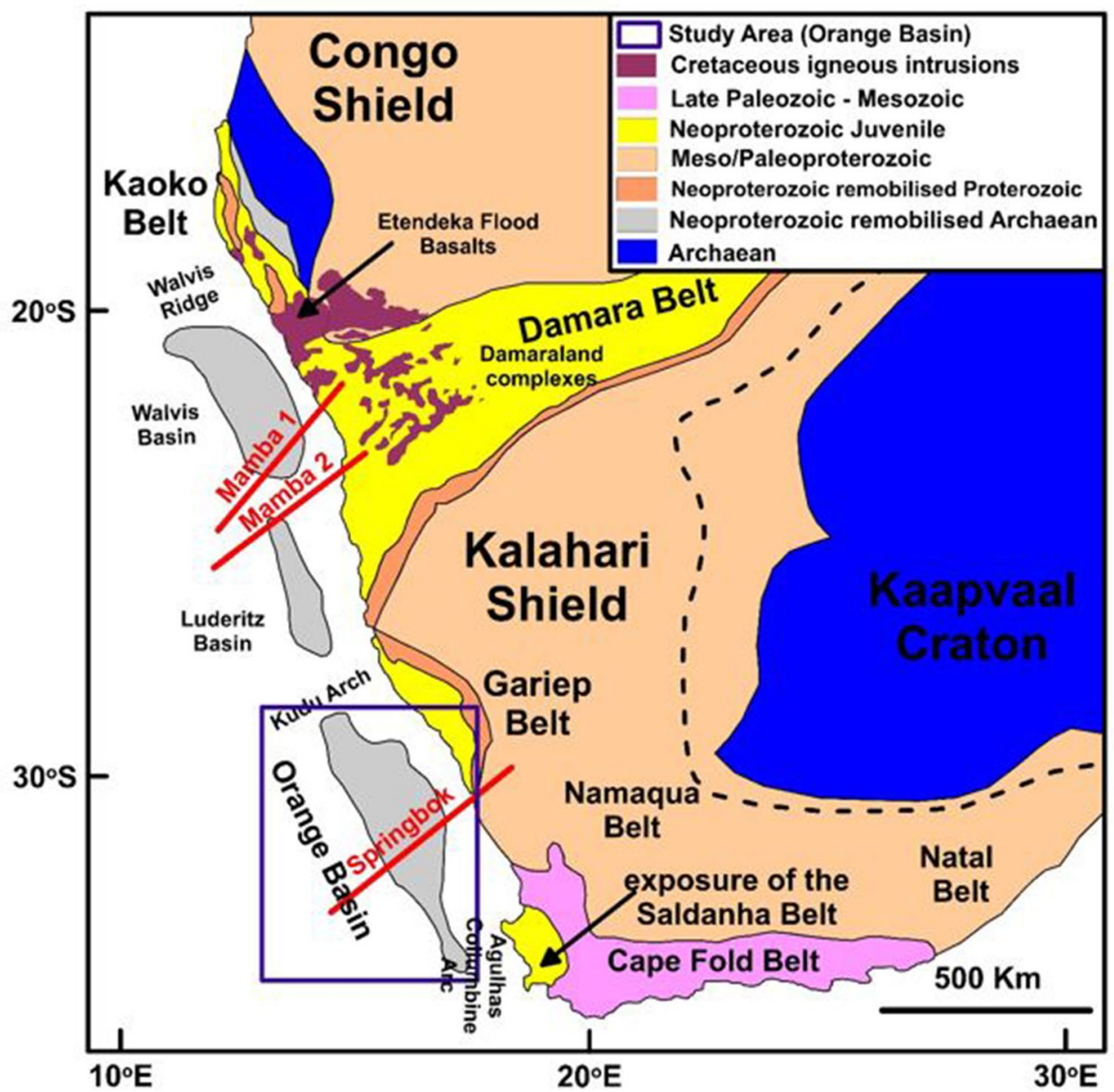

were rinsed with solvent to neutralize any contaminant and then oven-dried. About $150 \mathrm{ml}$ of the solvent was poured into the conical flask, and then alumina was added to avoid bumping and immediate evaporation of the solvent. Copper metal was also added into the conical flask of the solvent to absorb sulfur contained in the shale sample. The conical flask containing the solvent, anti-bump alumina, and $\mathrm{Cu}$ was mounted on the Soxhlet extractor, which housed the sample in the thimble and was connected to a condenser for $72 \mathrm{~h}$ of mantle heating. The extracted organic matter was separated using liquid column chromatography into saturated hydrocarbons, aromatics, and hetero-NSO fractions, which were then dried at room temperature before being investigated using gas chromatography (GC) or gas chromatography mass spectrometry (GC/MS).

\section{Molecular approach and isotope method}

The GC and GCMS were used on the aliphatic and aromatics to show the distribution of n-alkane, isoprenoid (Fig. 3a), hopane (Fig. 4a), and sterane (Fig. 5a) as well as some aromatic hydrocarbon fractions (Fig. 6a, b). Saturated fractions were mixed with hexane and analyzed using the gas chromatographs of the Agilent 6890 N series. A gaseous spectrometer FID coupled with an HP-5MS capillary was used for gas chromatography analysis, with intervals of 40 to $300{ }^{\circ} \mathrm{C}$ relative to $4{ }^{\circ} \mathrm{C}$ per minute, toward $300{ }^{\circ} \mathrm{C}$ for $30 \mathrm{~min}$. Similarly, an Agilent V5975B-MSD mass spectrometer outfitted with gas chromatographs and ion sources was adjusted for gas chromatographic mass spectroscopic analysis. By scaling the peak heights of the n-Alkanes, isoprenoids and aromatic hydrocarbon parameters, Table 1; terpane, Table 2; and sterane/diasterane, Table 3 mass fingerprints, biomarker

Fig. 3 a: Unimodal mass fragmentogram of $\mathrm{m} / \mathrm{z} 85$ representative samples showing isoprenoid and $n$-alkane distribution. $\mathrm{Pr}=$ Pristane and $\mathrm{Ph}=$ Phytane, while $\mathrm{nC}$ indicate carbon numbers. b: Cross-plots of Pristane/n- $\mathrm{C}_{17}$ against phytane/n- $\mathrm{C}_{18}$ showing organic matter. $\mathbf{c}$ : Cross-plots of Pristane $/ \mathrm{n}-\mathrm{C}_{17}$ against phytane $/ \mathrm{n}-\mathrm{C}_{18}$ showing organic matter source input, maturation of investigated Orange basin samples (Modified after Connan and Cassou 1980). d: Cross plots of CPI versus $\mathrm{Pr} / \mathrm{Ph}$ illustrating marine setting (after Meyers and Snowdon 1993). e: Cross-plot of waxiness vs $\mathrm{Pr} / \mathrm{Ph}$ showing preponderance of more anoxic $\mathrm{OM}$ 
Journal of Petroleum Exploration and Production Technology (2022) 12:307-339

311

(a)

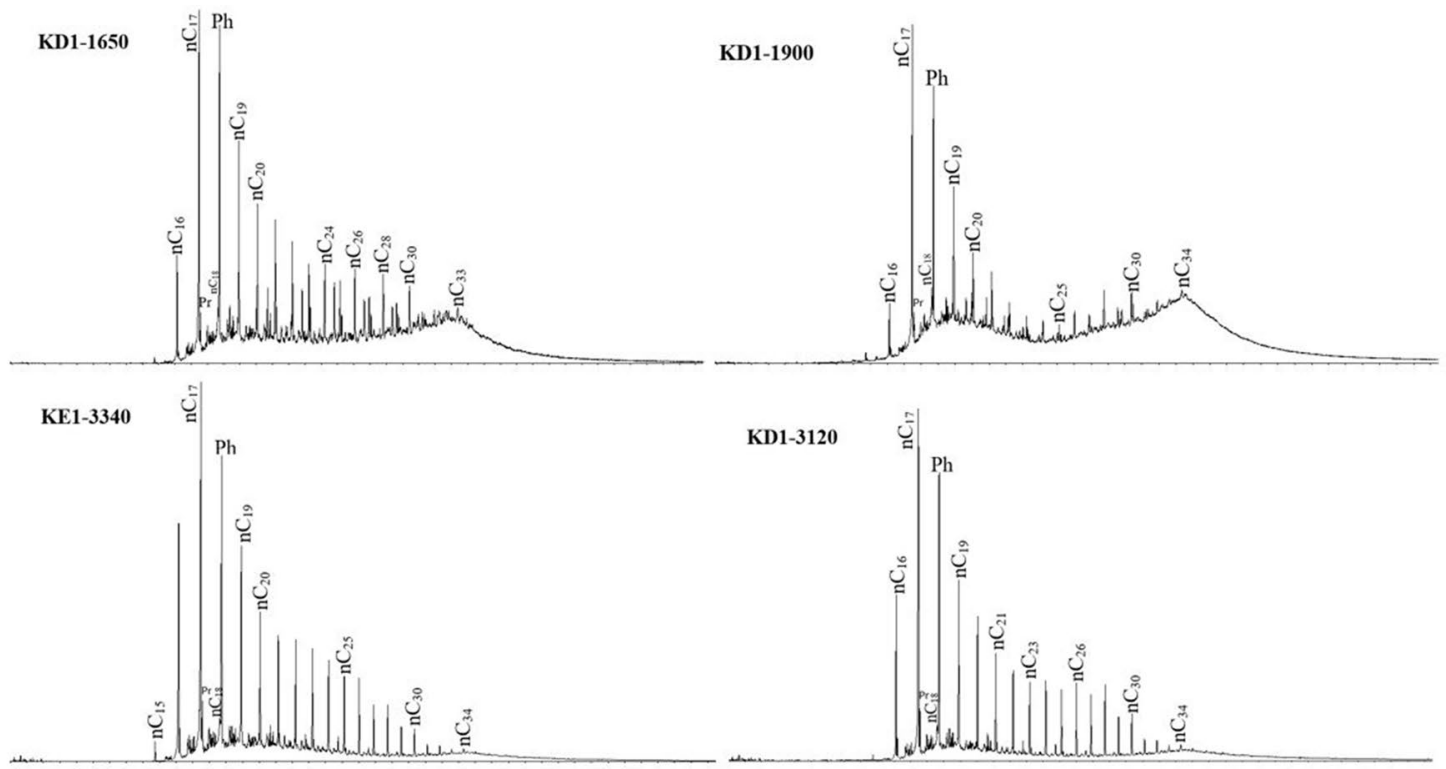

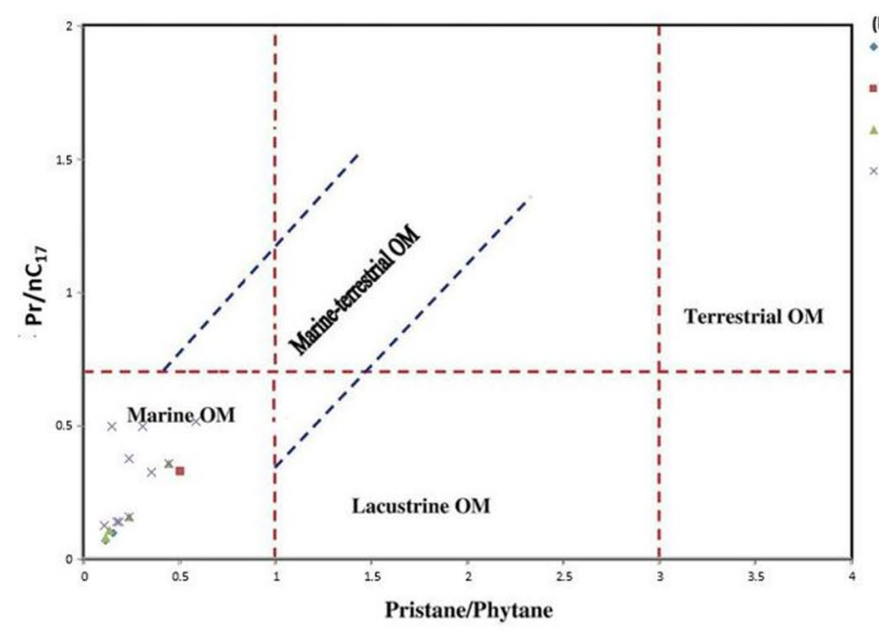

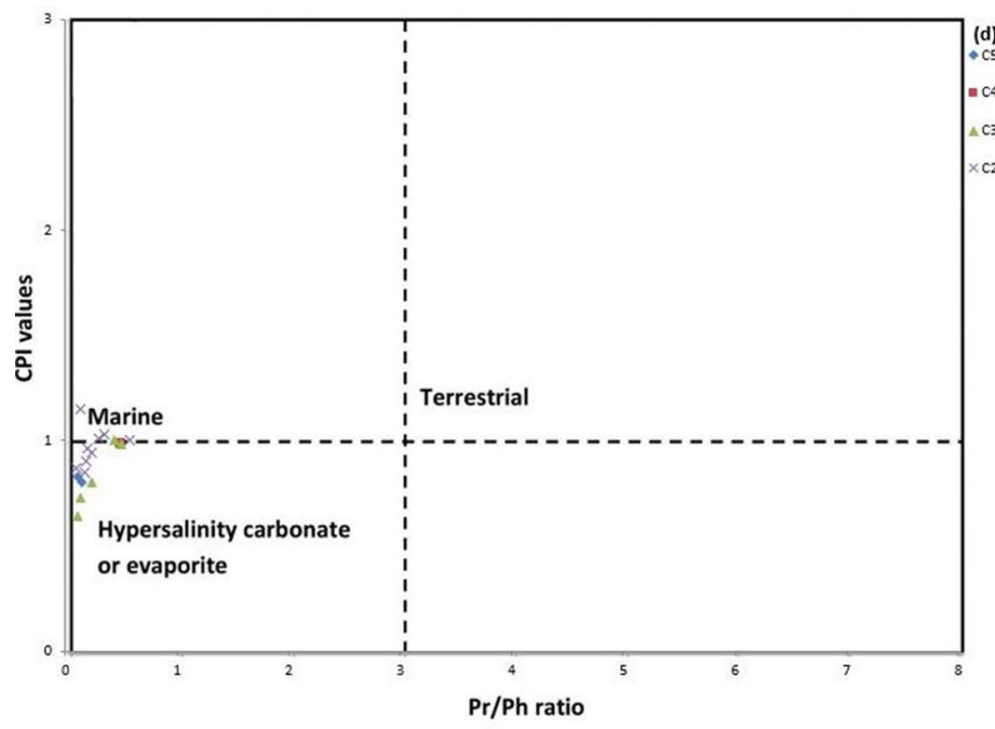

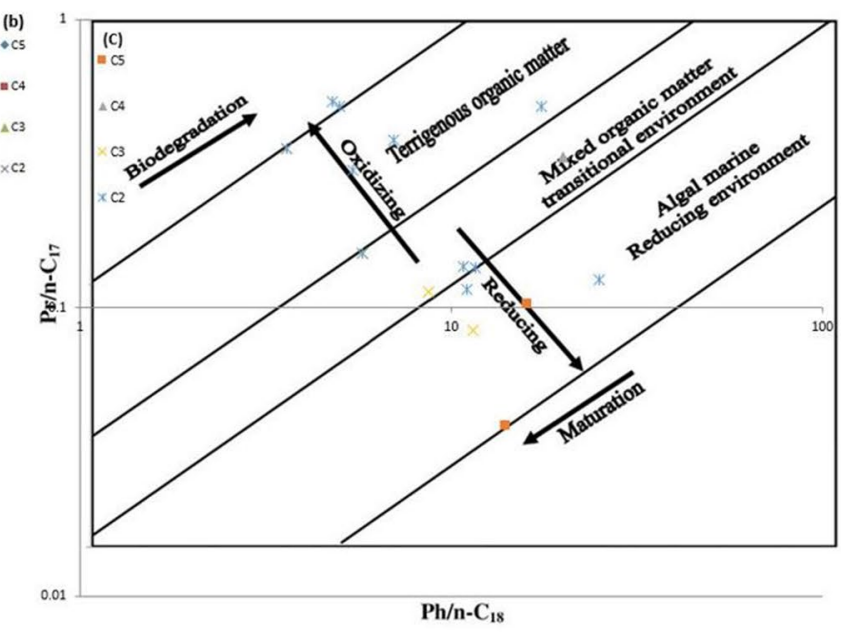

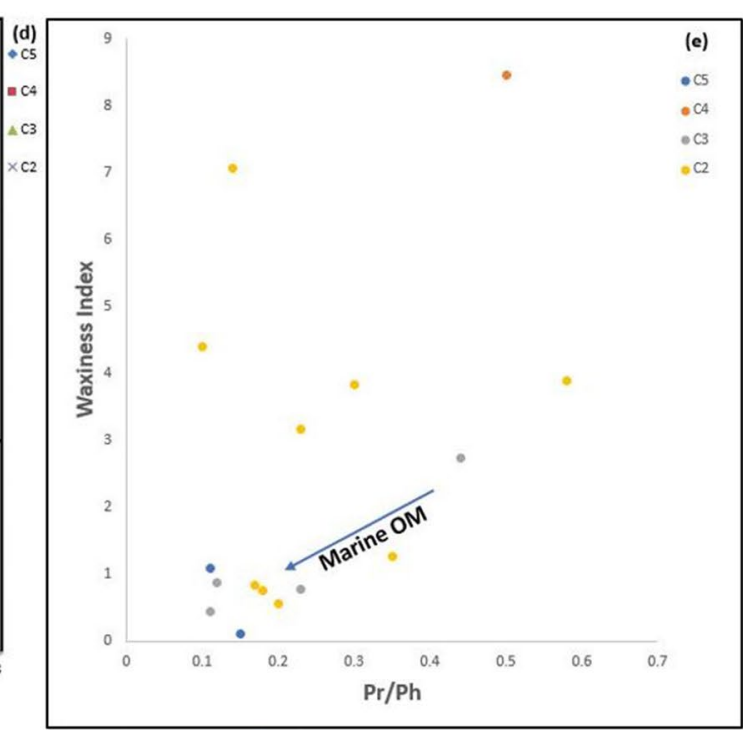

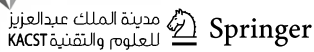



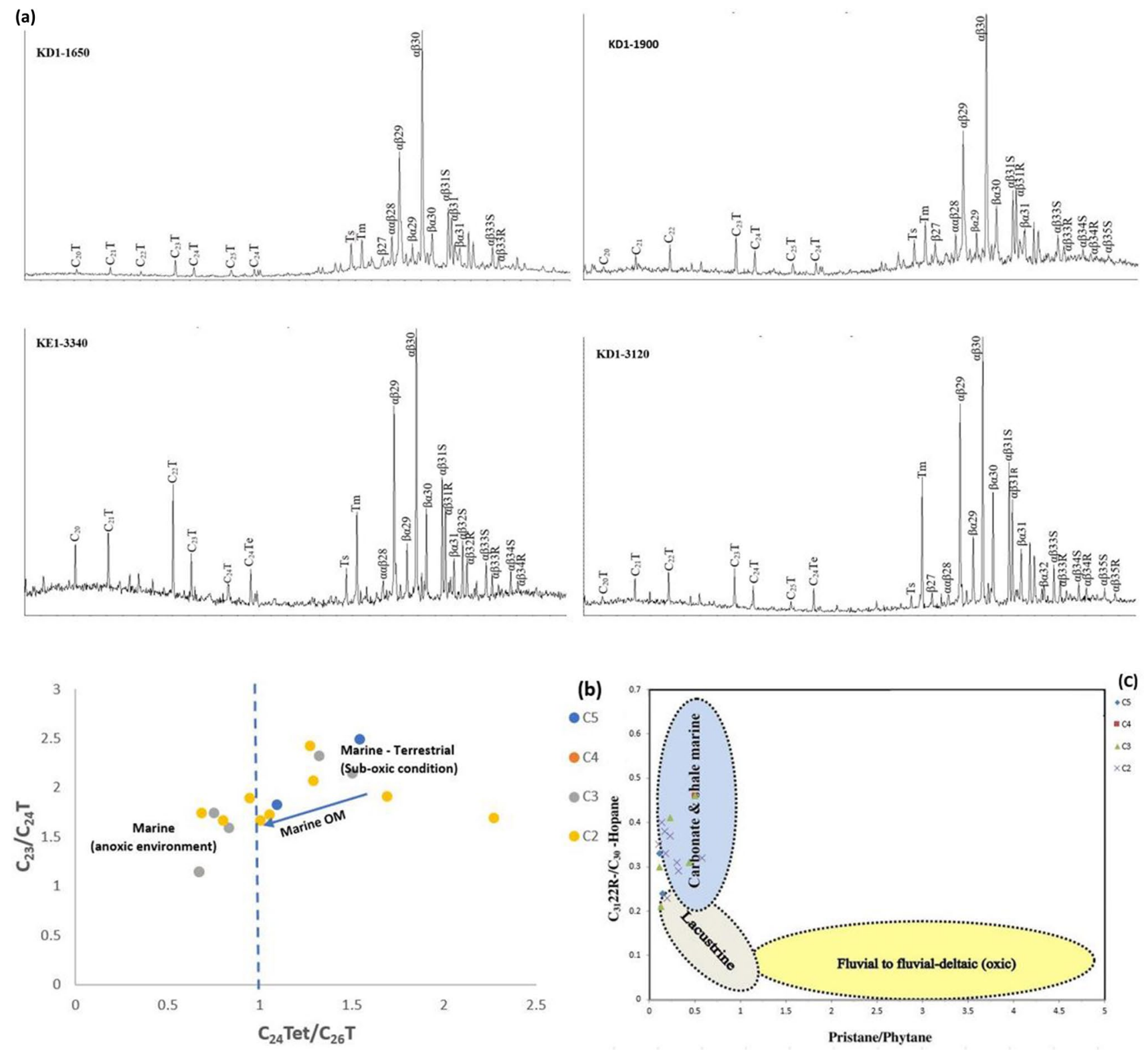

Fig. 4 a: Saturated mass fragmentogram of Terpanes; m/z 191 for investigated Orange Basin samples labeled with their respective peaks, carbon atoms and stereochemistry. b: The cross plot of $\mathrm{C}_{23} /$ $\mathrm{C}_{24}$ tricyclic terpane versus $\mathrm{C}_{24}$ tetracyclic/ $\mathrm{C}_{26}$ tricyclic indicating

significant marine source input with some terrigenous contributions. Note that this illustration Coincides with trace element findings. c: $\mathrm{C}_{31} 22 \mathrm{R} / \mathrm{C}_{30}$ versus $\mathrm{Pr} / \mathrm{Ph}$

imprints were adapted for molecular geochemical identification. Individual compounds were derived based on retention time and compared to previous work's mass spectrum (Adebanji et al. 2014). The GCMS was performed at the Geology Department, University of Malaya. Peak heights from ion-chromatograms were integrated to calculate aromatic hydrocarbon ratios (Van Aarssen et al. 1999). Agilent ChemStation software was used to process the data collected. For m/z 85, 191, 217 (branched/cyclic) and m/z 178, 184, 192 aromatics, the mass spectrometer was chosen. The bulk

stable carbon isotope $\left({ }^{13} \mathrm{C} /{ }^{12} \mathrm{C}\right)$ of the whole rock sample was determined using an isotopic mass spectrometry apparatus and the combustion method (Sofer 1980). According to the global standard, the outcome was a delta, represented by the Pee Dee Belemnite (PDB).

\section{Inorganic geochemical methods}

According to Pi et al. (2013), the whole rock samples were pulverized and digested to examine some major and trace 
(a)
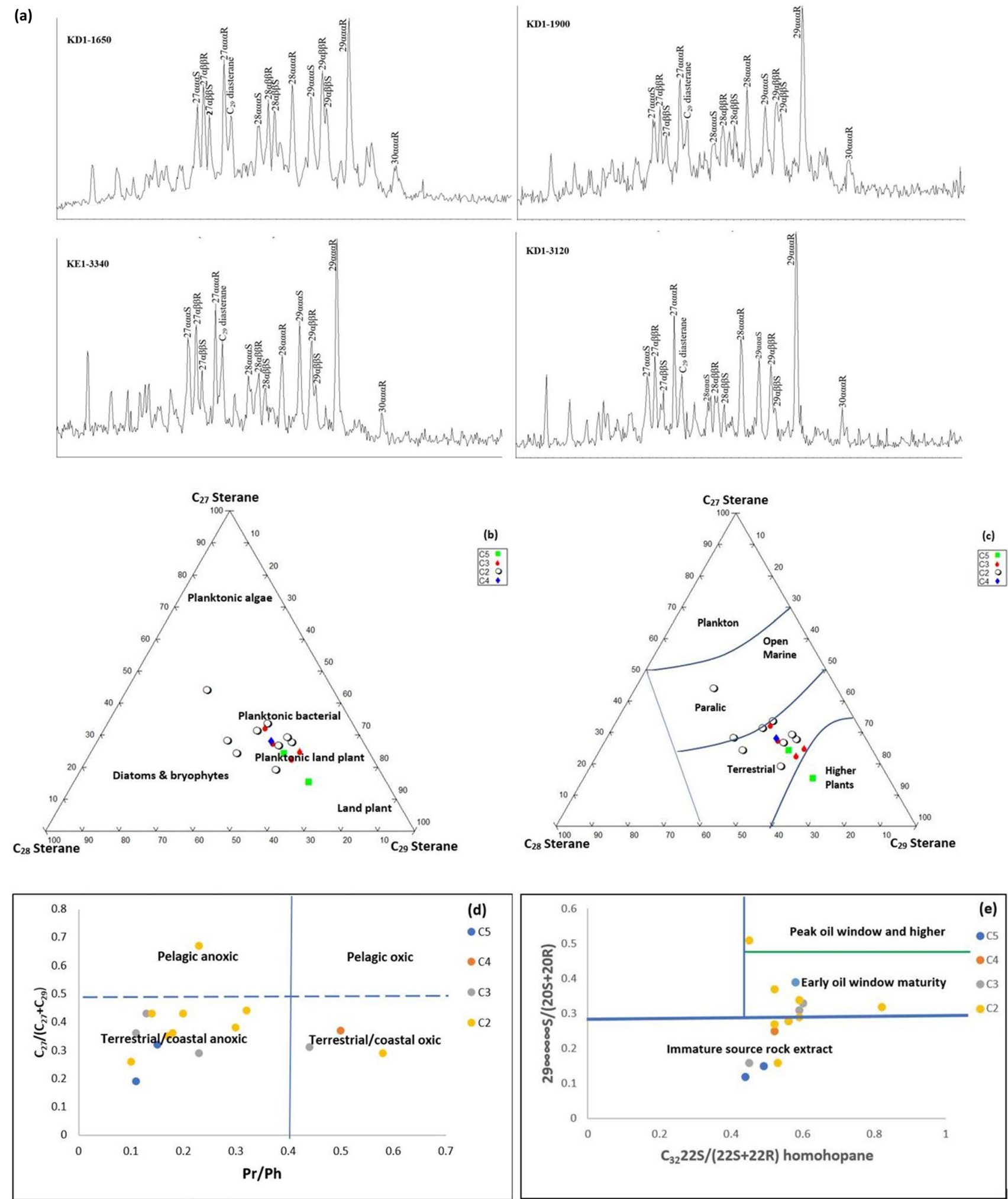

Fig. 5 a: Saturated mass fragmentogram of steranes; m/z 217 for investigated Orange basin shaly samples.b: Triangular plot correlating sterane composition with source input (after Huang and Meinschein 1979).c: Triangular plot correlating sterane composition with environment of deposition (after Huang and Meinschein 1979)d: Cross plot of $\mathrm{C}_{27} /\left(\mathrm{C}_{27}+\mathrm{C}_{29}\right)$ regular steranes against pristane/phy-

tane ratios illustrating depositional environment settings and sourceinput (Modified after Hossain et al. 2009)e: Cross-plot of two biomarker parameters responsive to thermal maturation source rock samples illustrating early to peak oil maturityof some samples. Modified from Peters and Moldowan (1993) 

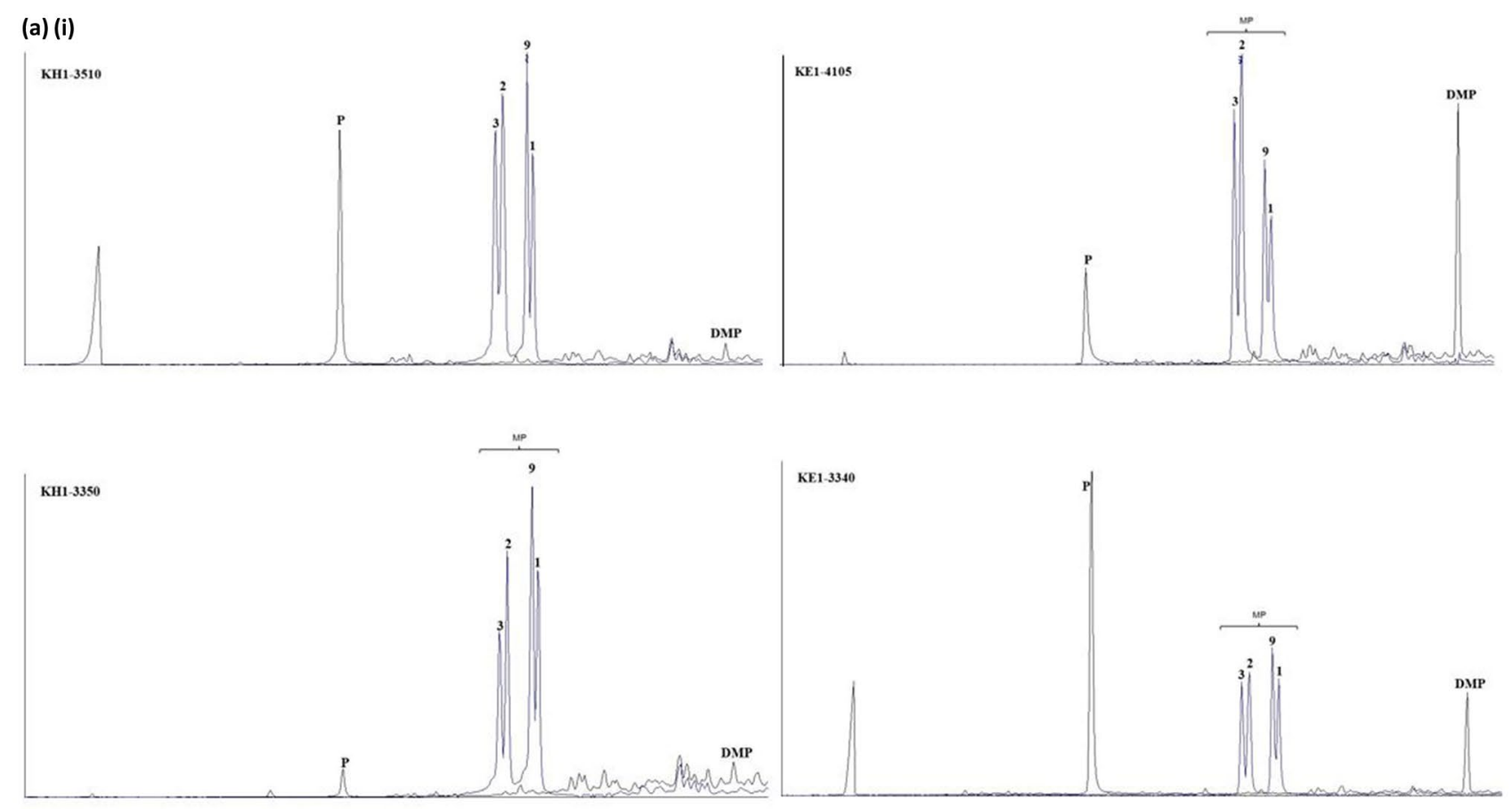

(a) (ii)
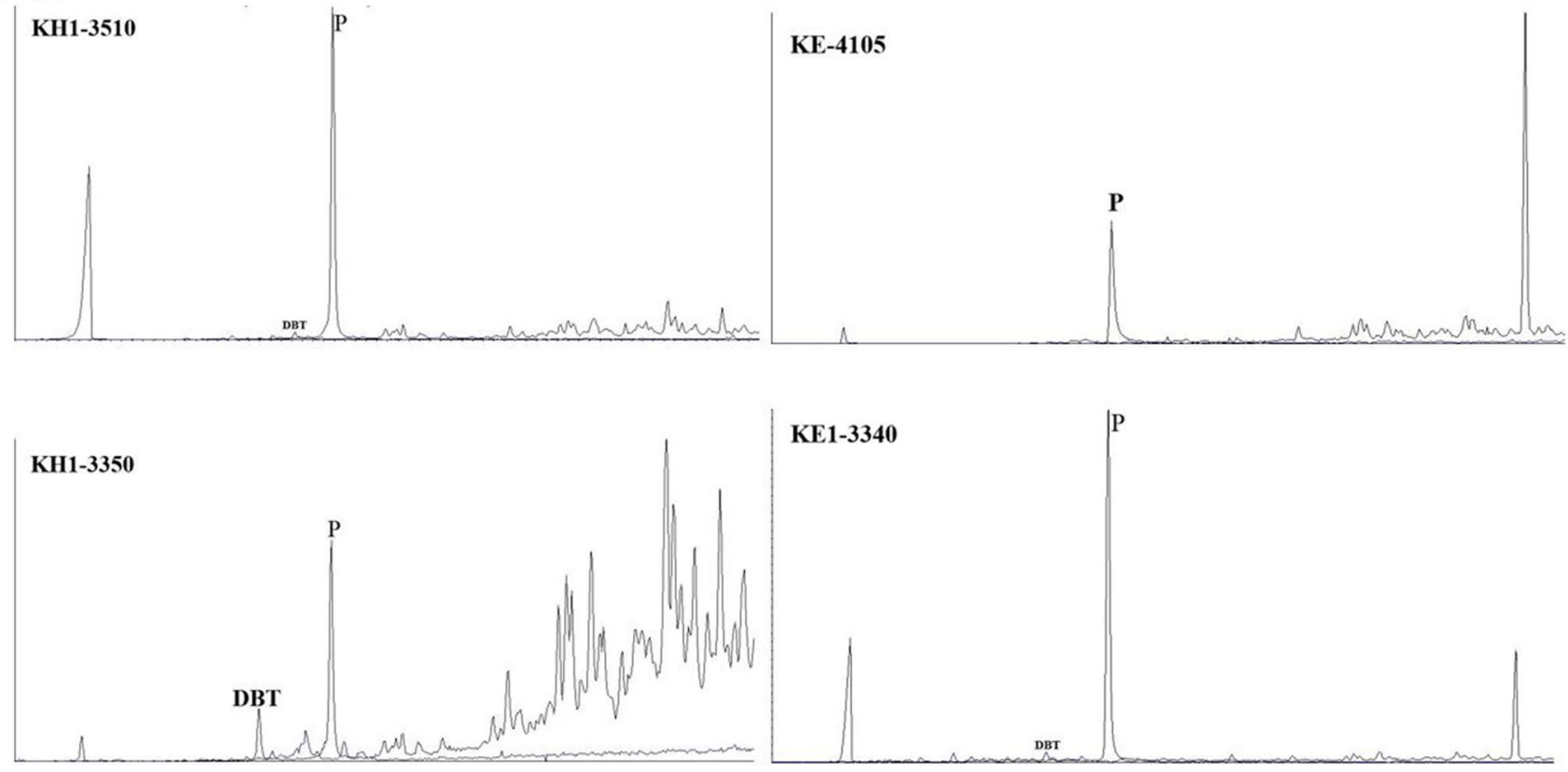

Fig. 6 a (i): Aromatic mass fragmentogram of Phenanthrene (P; m/z 178), Methylphenanthrene (MP; m/z 192). a (ii): Aromatic mass fragmentogram of Phenanthrene ( $\mathrm{P} ; \mathrm{m} / \mathrm{z}$ 178), plus aromatic Dibenzothiophenes (DBT; m/z 184) for Orange basin samples. b: $\mathrm{m} / \mathrm{z}$

elements. On a finely crushed sample, an X-ray fluorescing spectrometer (XRF) investigation was carried out using a P-analytical Axios mAX $4 \mathrm{~kW}$ sequenced XRF spectrometer. An indestructible wavelength dispersive X-ray fluorescing spectrometer was used to determine major and trace oxides (WDXRF). $0.50 \mathrm{~g}$ of samples were placed in a Teflon
$184+198+212$ mass peaks for the Orange basin samples where $1^{>} 4$ > $2+3$ methyldibenzothiophene. c: Plot of 9MP/9MP $+1 \mathrm{MP}$ ratio versus aquatic macrophyte n-alkane proxy (Paq) of the examined shaly samples (Modified after Ficken et al. 2000)

beaker and dehydrated overnight at $105^{\circ} \mathrm{C}$ to determine the concentration of minute traces and rare earth elements. The shales were dampened with milliliters of de-ionized aqueous solution; $5 \mathrm{ml} \mathrm{HNO}_{3}$ was added and placed on a hotplate at $150{ }^{\circ} \mathrm{C}$ just before drying; $10 \mathrm{ml} \mathrm{HF}$ was added, followed by $4 \mathrm{ml} \mathrm{HClO}_{4}$. The solution was heated to $200{ }^{\circ} \mathrm{C}$ using 
(b)
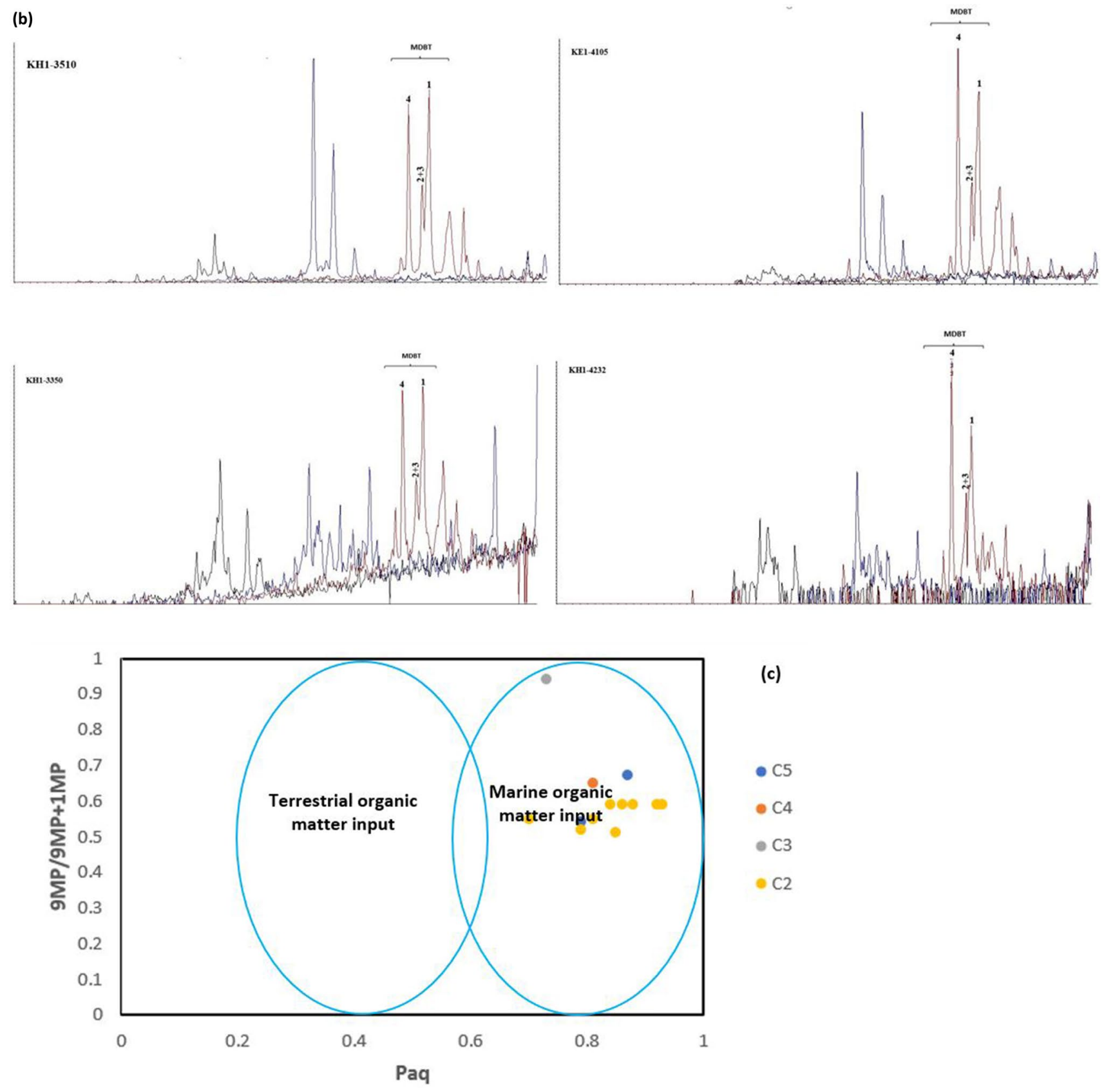

Fig. 6 (continued)

a crystalline mush until it was nearly dry. The settled and cooled samples were digested in a fume hood with $10 \mathrm{ml}$ of $5 \mathrm{M} \mathrm{HNO}_{3}$. The solutions were diluted using de-ionized water in 50-ml volumetric flasks, and ultra-pure water was used to dilute the digested samples up to 100 times. $10 \mathrm{ppm}$ analytic-concentration-standard element solutions were used for calibration, and the detection limit was set at less than one ppb. Trace elements were examined using the Agilent Technologies 7500S-ICP-MS.

\section{Result and discussion}

Molecular properties and organic matter as a source of input

\section{Normal alkane containing pristane and phytanes}

The fragmentogram of some of the samples studied, such as KD1-2250 and KH1-4232, contain low-to-moderate humps. Though, the n-alkanes extend further than $\mathrm{C}_{31}$, the humpy 


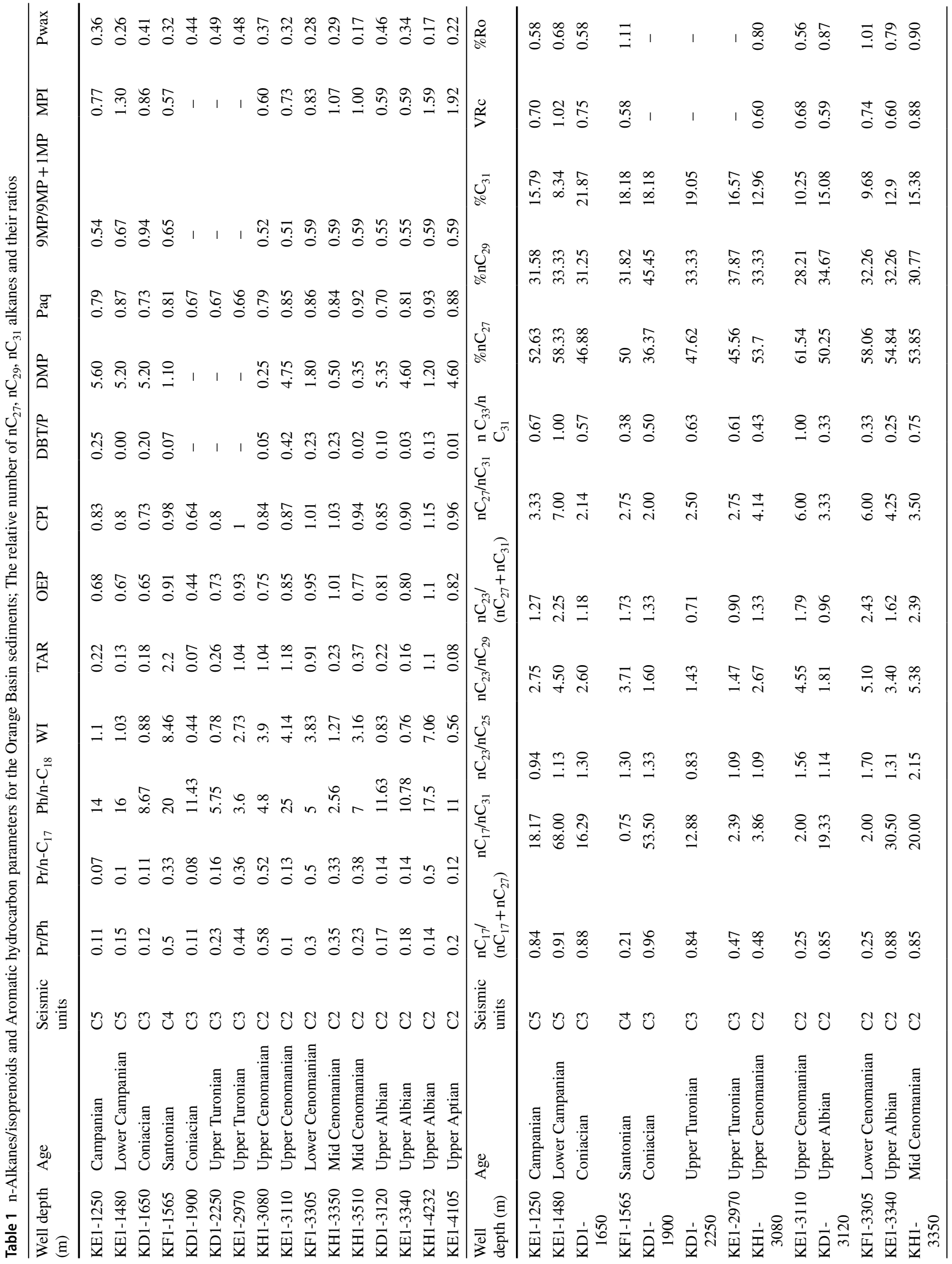


characteristics of some samples indicate low biodegradation (Volkman 1986). The fragmentograms show unimodal distributions of $n$-alkane and isoprenoids, additionally, low-tointermediate-weight compounds predominate $\left(n-C_{16}-n-C_{26}\right)$ (Fig. 3a), with high $\mathrm{Ph}$ peak illustrating reducing peaks as the number of n-alkane carbon atoms increases (Fig. 3a). In view of these characteristics, a marine carbonate source is more likely to contain algal-derived organic matter (Fig. 3b, d). Based on this data combined with $\mathrm{Pr} / \mathrm{n}-\mathrm{C}_{17}$ against $\mathrm{Pr} /$ $\mathrm{Ph}$ cross plot (Fig. 3b), oils are expected to generate and expel from marine carbonate source rock (Fig. 3d). Lowto-moderate-weight compounds with remarkable $+\mathrm{n}-\mathrm{C}_{26}$ carbon atoms yield waxiness indexes ranging from 0.44 to 8.46 and values of the CPI range from 0.73 to 1.15 (Table 1). This evaluation is typical of marine shales with mixed algae that have terrestrial organic matter inputs (Fig. 3c, e). Comparison of $\mathrm{Pr} / \mathrm{n}-\mathrm{C}_{17}$ vs $\mathrm{Ph} / \mathrm{n}-\mathrm{C}_{18}$ in cross plots (Fig. $3 \mathrm{c}$ ) show that algae-reducing environments predominate. These source rocks were genetically obtained via the same carbonate-rich lithofacies accumulated under a reducing to an oxidizing setting signifying primitive deposition of marine with mixed organic remains under reducing anoxic settings of the source rocks (Fig. 3b, d). Pr/Ph ratios range from 0.10 to 0.58 , indicating a high aquatic contribution (Lijmbach 1975) accumulating under anoxia (Makeen et al. 2015). The ratio of Pristane to Phytanes is commonly used to depict paleoxygenation settings (Escober et al. 2011), which is higher with greater thermal maturation (Connan and Cassou 1980) and more terrestrial remains. Similarly, as salinity increases, $\mathrm{Pr} /$ $\mathrm{Ph}$ ratio falls (Peters et al. 2005). Lesser $\mathrm{Pr} / \mathrm{Ph}$ (0.10-0.58), higher $\mathrm{Ph} / \mathrm{n}-\mathrm{C}_{18}(2.56-20)$, and moderate C.P.I. (0.64-1.15) under anoxic, saline water column with some terrestrial input is the source of rock on the western coast, according to the extracts (Fig. 3d, e; Peters et al. 2005; Bechtel et al. 2012). Comparison of $\mathrm{Pr} / \mathrm{n}-\mathrm{C}_{17}$ vs $\mathrm{Ph} / \mathrm{n}-\mathrm{C}_{18}$ in cross-plots (Fig. 3c) shows that algae-reducing environments predominate. These source rocks were derived genetically from the same carbonate-rich lithofacies that accumulated from a reducing to an oxidizing environment. Under the reducing anoxic settings of the source rocks, primitive deposition of marine with mixed organic remains occured. Based on this data combined with $\mathrm{Pr} / \mathrm{n}-\mathrm{C}_{17}$ against $\mathrm{Pr} / \mathrm{Ph}$ cross-plot (Fig. 3b), hydrocarbons are expected to generate and expel from marine carbonate source rock.

\section{Terpanes}

Tricyclic terpanes found in source rock samples were used to characterize the rocks, correlate oils and extracts, and determine thermal maturation (Zumberge 1987; Peters et al. 2005). The extent of anoxic in mixed sediments is defined by $\mathrm{C}_{22} \mathrm{~T}$ vs $\mathrm{C}_{21} \mathrm{~T}, \mathrm{C}_{24} \mathrm{~T}$ vs $\mathrm{C}_{23} \mathrm{~T}, \mathrm{C}_{25} \mathrm{~T}$ vs $\mathrm{C}_{26} \mathrm{~T}$, and $\mathrm{C}_{24} \mathrm{Tet} /$ $\mathrm{C}_{26} \mathrm{~T}$ ratios (Table 2; Zumberge et al. 2005; El Diasty et al.

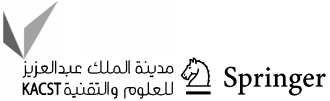




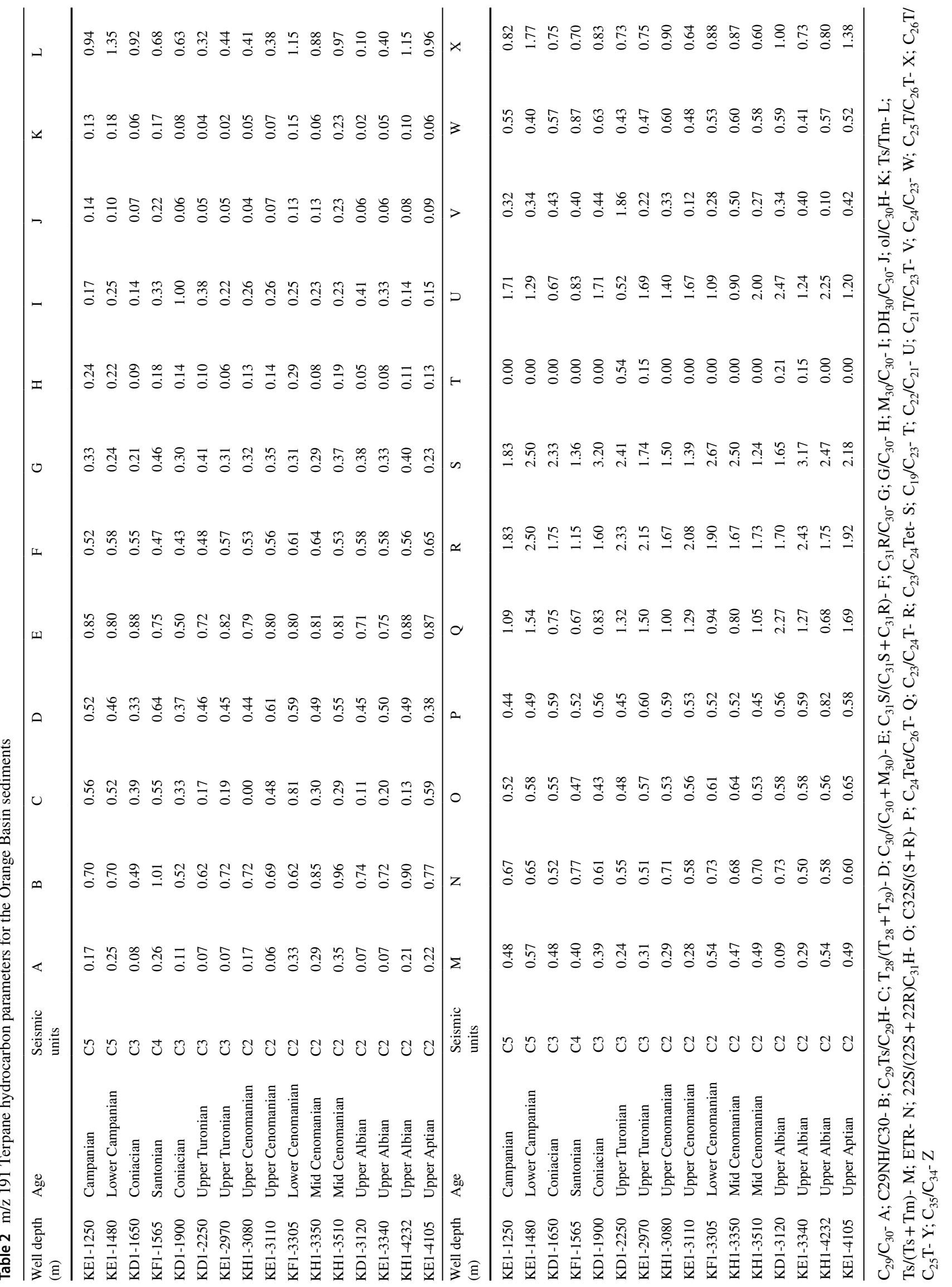




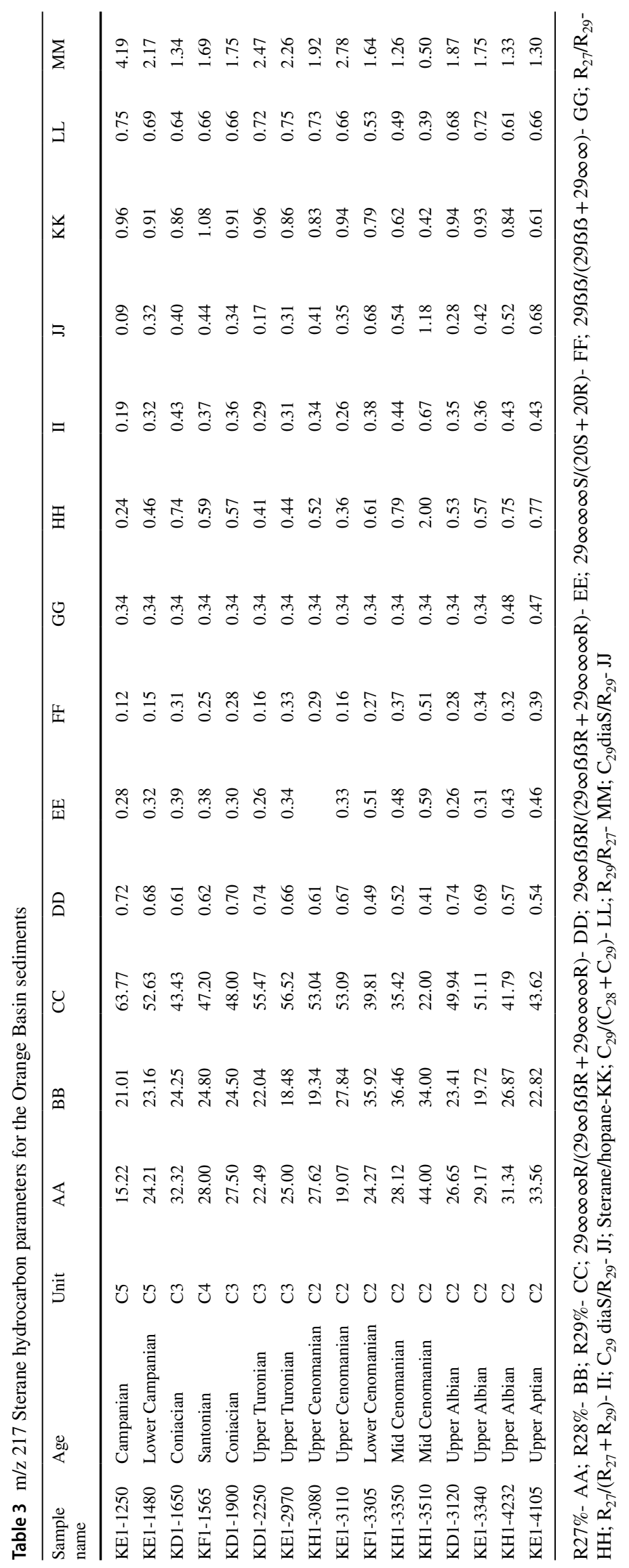


2016). Similarly, increasing marine source input are featured by cross-plots, as shown in Fig. 4b, c. Hopanoids (Fig. 4a) were made up of $\mathrm{C}_{29}$ norhopane, $\mathrm{C}_{30}$ hopane, some $\mathrm{C}_{31}-\mathrm{C}_{35}$ homohopanes, $\mathrm{G} / \mathrm{C}_{30}$, and $\mathrm{Tm}$. In all samples, $\mathrm{C}_{30}$ hopane predominates over $\mathrm{C}_{29}$ norhopane, as shown in Fig. $4 \mathrm{a}$ and Table 2, except for KH1-1565, which has a $\mathrm{C}_{29}$ norhopane/ $\mathrm{C}_{30}$ hopane ratio of 1.01. This single sample was taken from an organic-rich carbonate evaporite rock (Zumberge 1984; Connan et al. 1986; Peters et al. 2005). $\mathrm{C}_{30} \mathrm{H}$ has a higher proportion than $\mathrm{C}_{29} \mathrm{NH}\left(\mathrm{C}_{29}\right.$-norhopane/ $\mathrm{C}_{30} \mathrm{H}$ ratio of less than 1) characterizing abundant clay materials in the rocks (Gurgey 1999), as confirmed by $\mathrm{C}_{29}$ diasterane/ $\mathrm{R}_{29}$ with 87 percent of analyzed samples greater than 0.2 , indicating a suboxic deposition condition (Makeen et al. 2015; Moldowan et al. 1994; Peters et al. 2005). Thus, extracts have moderate-to-high amounts of pentacyclic and tricyclic terpane with less tetracyclic as determined by $\mathrm{C}_{24} \mathrm{Tet} /$ $\mathrm{C}_{26}$ T ranging between 0.67 and $2.27 ; \mathrm{C}_{23} \mathrm{~T} / \mathrm{C}_{24} \mathrm{~T}$ ranging between 1.24 and 2.50 , indicating reasonable terrestrial matter contributions (Fig. 4b). The high preponderance of $\mathrm{C}_{23} \mathrm{~T}$ over $\mathrm{C}_{24} \mathrm{~T}\left(\mathrm{C}_{23} \mathrm{~T} / \mathrm{C}_{24} \mathrm{~T}\right)$ 1.15-2.50 confirms microbial action within the examined samples, indicating a dysoxic environment. Furthermore, tricyclic terpane ratios based on the number of carbon atoms have been identified as a means of better understanding source input (Peters et al. 2005). The existence of average to high $\mathrm{C}_{24} \mathrm{~T} / \mathrm{C}_{23} \mathrm{~T}$ values ranging from 0.40 to 0.87 indicates the presence of both marine and terrestrial matter (Marynowski et al. 2000). $\mathrm{C}_{21} / \mathrm{C}_{23} \mathrm{~T}$ less than 0.5 indicates that the rock came from the sea (Quihua et al. 2011). The $C_{21} T / C_{23} T$ ratio in the examined samples ranges from 0.10 to 0.50 , with only one sample having 1.86 (KD12245). The source rocks were formed in a marine anoxic environment with terrestrial input (Fig. 4b). The ratio of $\mathrm{C}_{26} \mathrm{~T}$ to $\mathrm{C}_{25} \mathrm{~T}$ was modified to distinguish between bacterial and terrestrial plant matter (Volk et al. 2005). Low-tomedium $\mathrm{C}_{26} \mathrm{~T} / \mathrm{C}_{25} \mathrm{~T}$ values range from 0.57 to 1.67 in this shaly sediment, with 87 percent greater than 0.9 signifying a mixture of algal and bacterial organic materials making up slightly terrestrial input (Volk et al. 2005). A high $\mathrm{C}_{26} \mathrm{~T}$ versus $\mathrm{C}_{25} \mathrm{~T}$ ratio, a low-medium $\mathrm{C}_{24} \mathrm{~T} / \mathrm{C}_{23} \mathrm{~T}$ ratio, and a low-to-medium $\mathrm{C}_{22} \mathrm{~T} / \mathrm{C}_{21} \mathrm{~T}$ ratio indicate lacustrine mix primal matter (Aquino et al. 1989; Kruge et al. 1990; Peters et al. 2005; Volk et al. 2005; Makeen et al. 2015). Some carbon isotope results support this as well (Fig. 13). The $\mathrm{C}_{31}-22 \mathrm{R} / \mathrm{C}_{30} \mathrm{H}$ ratio is primarily high, exceeding 0.25 in the marine environment and falling below 0.25 in the lacustrine environment of deposition (Peters et al. 2005). $\mathrm{C}_{31}-22 \mathrm{R} /$ $\mathrm{C}_{30}-\mathrm{H}$ for investigated shales is between 0.21 and 0.46 , with carbonate and shaly marine source input accounting for $80 \%$ of examined samples and lacustrine influence accounting for 20\% (Fig. 4c; Peters et al. 2005).

Furthermore, aromatic fractions show low levels of aromatic compounds in some samples, indicating that the source rock depositional environment is marine (Radke et al. 2000). Lower DBT/P ratios indicate the incorporation of reducing primal sulfate matter (Hughes et al. 1995). Less DBT vs. P (Table 1) suggests algae with a minor terrestrial organic input. Gammacerane is present in all the shales studied, though in trace amounts in some (Table 2). It is made by reducing tetrahymanol (Venkatesan 1989). Tetrahymanol is produced by bacterivorous ciliates that live in the intervening oxic and anoxic realms of a high saline aqua layer separated by a less saline upper stratified aqua column (Ten Haven et al. 1988). Gammacerane is primarily used to calculate salinity in stratified water columns and is thought to be a marker of anoxic photic zones (Adebanji et al. 2015). The investigated $\mathrm{G}_{30}$ vs $_{30}$ ratio is between 0.05 and 0.24 (Table 2), indicating the presence of saline in the stratified aqueous column via the sedimentation of lower and upper post-rift deposits in the Orange Basin. Furthermore, $\mathrm{G}_{30} / \mathrm{C}_{30}$ indicates that the paleoxygenation condition of sediment accumulation was decreasing, as supported by $\mathrm{Pr} / \mathrm{Ph}$ values of less than 0.8 , even though the source rocks have freshwater lacustrine influences (Fig. 4c).

\section{Steranes}

Relative sterane richness is a significant quality shift in OM's biological origin that distinguishes source distinctness while distributing cholesterol from organisms (Fig. 5b, c). $\mathrm{C}_{29}$ sterane is abundant in terrestrial land plants, whereas animals and aquatic plants are primarily composed of sterols of $\mathrm{C}_{27}$ molecular weight, followed by $\mathrm{C}_{28}$ sterols. Sterane $\mathrm{C}_{27}$ is primarily found in algae, while Sterane $\mathrm{C}_{29}$ is found in higher terrestrial plants. Limnic conditions are characterized by low $\mathrm{C}_{28}$ sterol concentrations (Volkman 1986). Similarly, micro-algae and cyanobacteria are good sources of $\mathrm{C}_{29}$ sterols. The analyzed shales contain more $\mathrm{C}_{29}$ sterols (22.00-63.77 percent) than $\mathrm{C}_{27}(15.22-44.00$ percent) and $\mathrm{C}_{28}$ (18.48-36.46 percent) steranes, implying abundant terrestrial input as opposed to planktonic bacterial to algae organic matter, as shown by the regular steranes triangular plot (Fig. 5b). In other words, except for KH1-3510, which is " $L$ " type, the regular sterane is an anti-" $L$ " type that is predominantly found in land plants $\left(\mathrm{C}_{27} / \mathrm{C}_{29}<1\right)$. It should be noted that the dominance of $\mathrm{C}_{29}$ in planktonic land plant input is relatively much higher in KE1-1250 (63.77 percent) and in KH1-3510 (22 percent). A tri-plot of the $\mathrm{C}_{27}, \mathrm{C}_{28}$, and $\mathrm{C}_{29}$ distributions indicates the type of primal matter as mixed marine-terrigenous source inputs (Fig. 5b, c). The relatively low sterane vs hopane ratio (Table 3 ) distinguishes terrestrial or microbial rework matters (Tissot and Welte 1984). Steroids and hopanoid constituents differ between organisms; differences in sterane versus hopane allow only a qualitative evaluation of eukaryotes and prokaryotes' source 
inputs (Peters et al. 2005; Seifert and Moldowan 1978). Pr/ $\mathrm{Ph}$ and $\mathrm{C}_{27} /\left(\mathrm{C}_{27}+\mathrm{C}_{29}\right) \mathrm{R}$ values range from $0.10-0.58$ to $0.19-0.67$, respectively, indicating that anoxic primal matter predominates in terrestrial/coastal anoxic environments (Fig. 5d). Furthermore, most samples have a highly anoxic paleoxygenation condition, with $\mathrm{Pr} / \mathrm{Ph}$ values less than or equal to 0.58 (Table 1 ).

According to Phenanthrenes, the source input index also provides information on the origin of marine organic matter (Fig. 6a). The Paq index supports this claim, which is defined as the absolute input of aquatic macrophytes as well as higher terrigenous remains (Ficken et al. 2000). Paq values less than 0.1 indicate unmixed terrigenous matter, while Paq values between 0.1 and 0.4 indicate abundant emergent plant contribution, and Paq values between 0.4 and 1 indicate abundant contributions of emergent macrophytes and submerged plant remains under anoxic conditions (Fig. 6c). There is a high concentration of marine inputs as indicated by Paq from 0.7 to 0.94 (Table 1). Furthermore, a measure of methyldibenzothiophene isomers (MDBT) in the Orange basin source rocks varies as follows: $1^{>} 4>2+3$ methyldibenzothiophene (Fig. 6b) synonymous to carbonate to shaly organofacies (Hughes et al. 1995). In addition, the peak distribution of methylphenanthrenes $\left(9^{\prime} 1^{\prime} 2^{\prime} 3\right.$; Fig. 6a (i)) and the predominance of 9-methylphenanthrene (9MP) over its isomers suggests that organofacies originated from marine input (Budzinski et al. 1995; Escobar et al. 2011). Most samples contain dimethylphenanthrenes and dibenzothiophene dimethylated duplicates. Based on aromatic biomarker analyses, the studied source rocks were accumulated in reduced anoxic carbonate settings. In conclusion, biomarker analysis reveals that the well " $K$ " sediments studied are genetically derived from the coastal marine environment as $\mathrm{Pr} v \mathrm{Ph}$ values ranging from 0.10 to 0.58 support this, indicating marine anoxic conditions (Fig. 3b; Taohua et al. 2018). These source rocks contain a significant number of algae and microbial marine primal matter, as well as some mixed organic remains deposited in a more reducing environment (Fig. 3c).

\section{Maturation of organic matter}

This expands on the extent to which OM is intensely heated and transformed into petroleum. The molecular specification for the ratio and distribution of biomarkers has been modified to investigate the degree of thermal maturation (Gogoi et al. 2021). To investigate the thermal maturation of the shaly sediments, a few molecular maturation determinants, such as the $\mathrm{C}_{29} \beta \beta(\beta \beta+\alpha \alpha)$ ratio, the $\mathrm{C}_{32} 22 \mathrm{~S} /(22 \mathrm{~S}+22 \mathrm{R})$ ratio, and the $\mathrm{M}_{30} / \mathrm{H}_{30}$ plus methylphenanthrene indices (MPI), were adapted (Table 1).

The sterane isomerization model is widely accepted as an OM maturity guide (Seifert and Moldowan 1978; Xuijian et al. 2016). $C_{29} \alpha \alpha \alpha R /(\alpha \beta \beta R+29 \alpha \alpha \alpha R)$ ratios in examined shales range from 0.41 to 0.74 (Table 3), a ratio of $\mathrm{C}_{29} \alpha \alpha \alpha \mathrm{S} /$ $(20 \mathrm{~S}+20 \mathrm{R})$ varies from 0.10 to $0.51 . \mathrm{C}_{32} 22 \mathrm{~S} /(22 \mathrm{~S}+22 \mathrm{R})$ hopane ratios (0.44-0.82) demonstrated that an equilibrium had been reached and that the shales were mature for hydrocarbon generation (Seifert and Moldowan 1986). With increasing thermic maturation, these fractions increase (Adekola et al. 2012). In the source rocks, the maximum $\mathrm{C}_{29} \alpha \alpha \alpha \mathrm{S} /$ $(20 \mathrm{~S}+20 \mathrm{R})$ values are 0.51 or less. These values propose that some of the examined shales are thermally mature to generate hydrocarbons, while others are immature (Fig. 5e). The mortane versus hopane $\left(\mathrm{M}_{30} / \mathrm{H}_{30}\right)$ reduces with rising thermic maturation between 0.8 for the immature extract and 0.15-0.05 matured sediments (Mackenzie et al. 1980; Peters et al. 2005). $\mathrm{M}_{30} / \mathrm{H}_{30}$ examined is from 0.14 to 1.00. KD11900 is immature, with an $\mathrm{M}_{30} / \mathrm{H}_{30}$ ratio of no more than 1.00.

$\mathrm{C}_{29}$ diasterane versus regular steranes were also suitable for detecting OM thermal maturity. Diasteranes are formed by the transformation of sterols, and diagenesis, as well as catagenesis, making them more balanced than steranes at higher maturation (Peters and Moldowan 1993; Peters et al. 2005). $\mathrm{C}_{29}$ diasterane/29 $\alpha \alpha \alpha \mathrm{R}$ ranges from 0.09 to 1.18 , indicating that most shales are mature enough for hydrocarbon generation. Other biomarker maturity parameters are Ts vs $(\mathrm{Ts}+\mathrm{Tm}), \mathrm{C}_{32} 22 \mathrm{~S} /(22 \mathrm{~S}+22 \mathrm{R}), \mathrm{M}_{30} / \mathrm{H}_{30}$, the $20 \mathrm{~S} /$ $(20 \mathrm{~S}+20 \mathrm{R})$, and $\mathrm{C}_{29} \beta \beta /(\beta \beta+\alpha \alpha)$ (Mackenzie et al. 1980; Waples \& Machihara 1991). Source input and thermal maturity of OM are represented by these ratios. This is based on OM source input and maturity in the case of $\mathrm{T}_{\mathrm{s}}$ vs $\left(\mathrm{T}_{\mathrm{S}}+\mathrm{T}_{\mathrm{m}}\right)$ and $\mathrm{T}_{\mathrm{s}}$ vs $\mathrm{T}_{\mathrm{m}}$ (Peters and Moldowan 1993). Tm is unstable during the catagenesis of hydrocarbon generations; as a result, Ts versus Tm increases with maturity (Seifert and Moldowan 1978). In the analyzed shales, the Ts/ (Ts + Tm) is from 0.09 to 0.57 (immature to early maturity).

$\mathrm{The} \mathrm{Ph} / \mathrm{n}-\mathrm{C}_{18}$ and $\mathrm{Pr} / \mathrm{n}-\mathrm{C}_{17}$ are homogeneous reflecting similar interpretations as for low-to-high thermal maturity (Fig. 3c). In comparison with other biomarker maturity parameters (Fig. 5e) and vitrinite reflectance measurements, the methylphenanthrenes index (Table 1; Radke and Welte 1983; Radke et al. 1982) yielded computed reflectance of vitrinite (VRc percent) ranging from 0.58 to 1.39. (Table 1). Despite inconsistencies in somethermal maturity parameters, the general trend in sample maturity is that, it increases with depth across each respective well. This disparity in maturation is attributed to the Orange basin's intricate infilling evolution and mixing.

\section{Elemental concentrations and distributions}

The genesis, conservation, accumulation, and paleoenvironmental setting of organic materials are significantly influenced by their bulk inorganic composition (Mohialdeen and Raza 2013; Shu et al. 2013; Jia et al. 2013; Moosavirada et al. 2011). Tables 4 and 5 summarize the

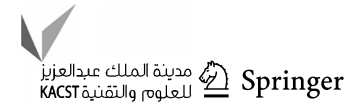




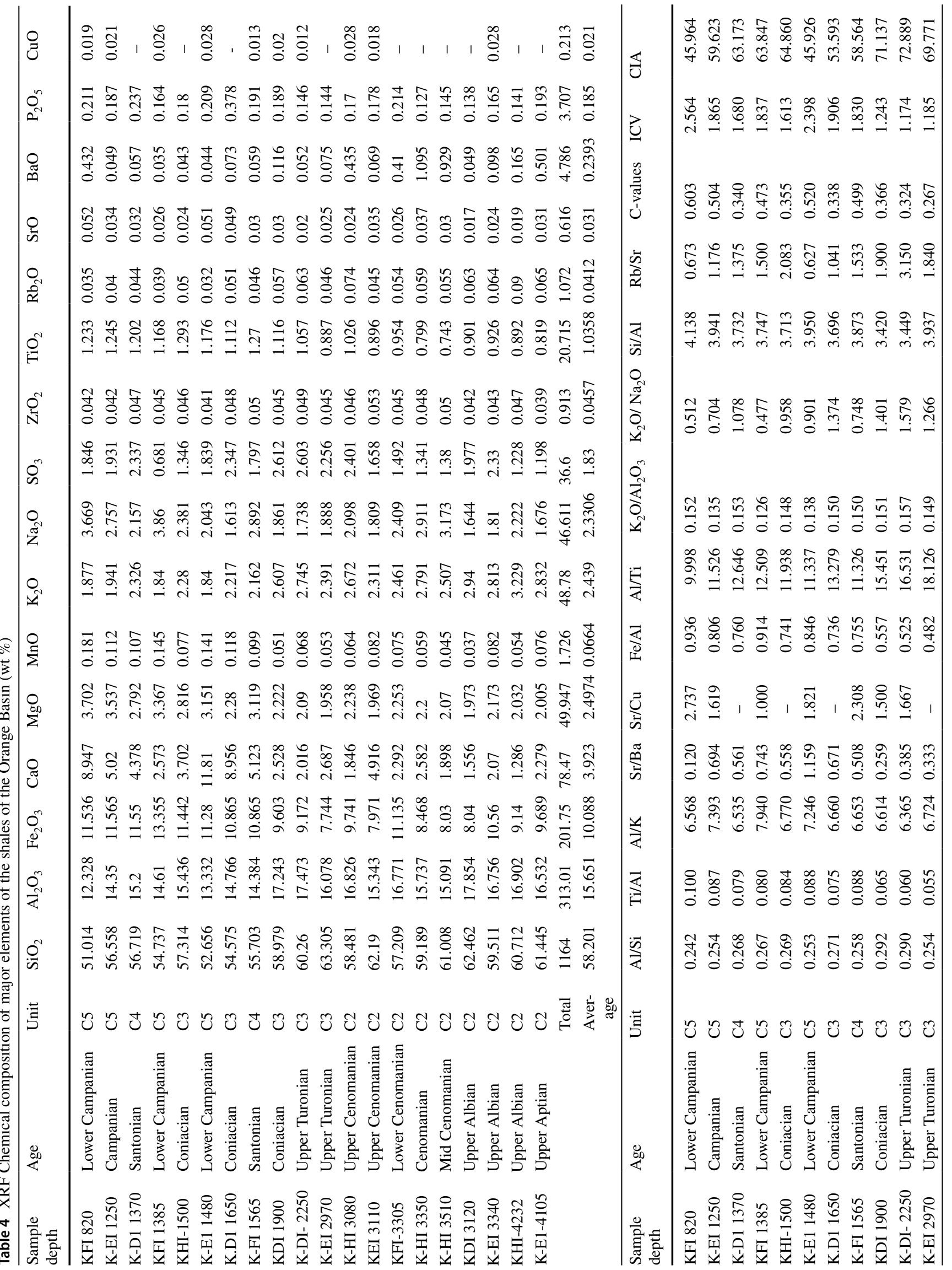




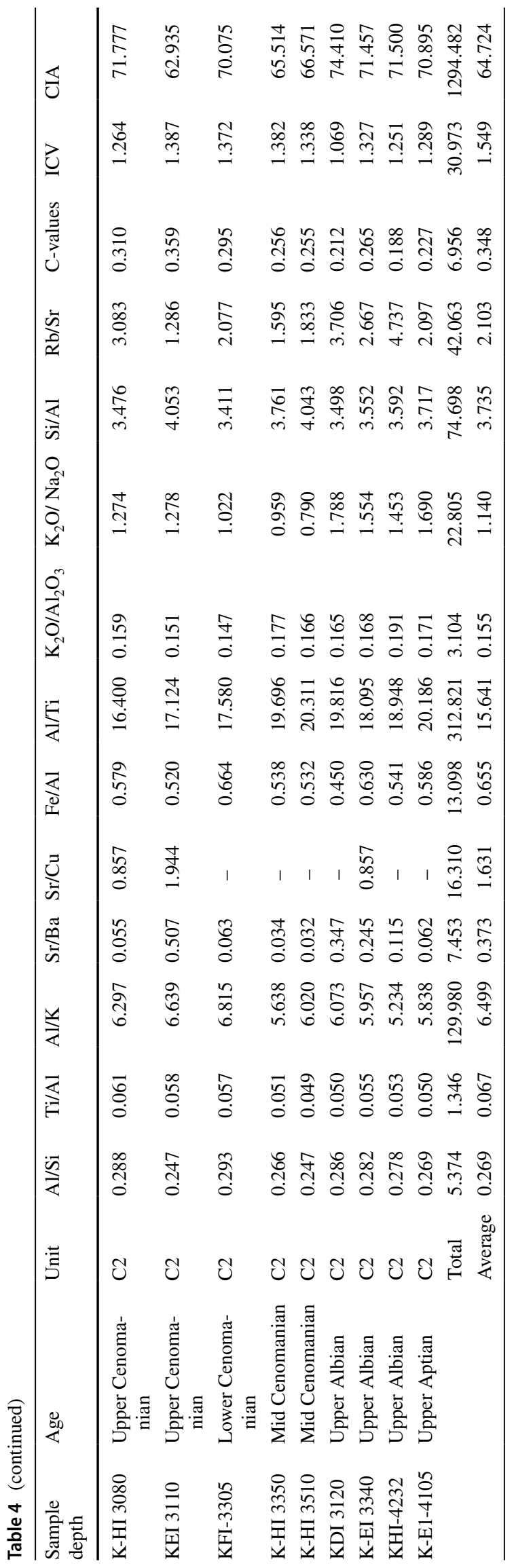

inorganic geochemical outcome within the examined shales, which includes major and trace oxides with applicable geochemical ratios.

\section{Major/trace element}

Major elements are commonly found in greater than $1 \%$ of major ores. These oxides were investigated using ICPMS and XRF equipment (Roy and Roser 2013; Peters et al. 2005). $\mathrm{SiO}_{2}, \mathrm{Al}_{2} \mathrm{O}_{3}, \mathrm{Fe}_{2} \mathrm{O}_{3}, \mathrm{CaO}, \mathrm{MgO}, \mathrm{K}_{2} 0, \mathrm{Na}_{2} 0, \mathrm{SO}_{3}$, $\mathrm{TiO}_{2}$ have average compositions of 58.20 percent, 15.65 percent, 10.10 percent, 3.92 percent, 2.50 percent, 2.44 percent, 2.33 percent, 1.83 percent, and 1.04 percent, respectively. Less than 1 percent is the average concentration of other major oxides, such as $\mathrm{Rb}_{2} \mathrm{O}, \mathrm{Zr}_{2} \mathrm{O}, \mathrm{Sr}_{2} \mathrm{O}_{5}, \mathrm{P}_{2} \mathrm{O}_{5}$, $\mathrm{BaO}, \mathrm{CuO}$, and $\mathrm{MnO}$. The major oxide have high $\mathrm{SiO}_{2}$ and $\mathrm{Al}_{2} \mathrm{O}_{3}$, indicating a quartz and clay mineral predominance, as expected in siliciclastic deposits. $\mathrm{Al} / \mathrm{Si}$ ratios ranging from 0.242 to 0.293 are extremely low, with an average of 0.269 , implying that $\mathrm{Si}$ comes from sources other than clay minerals (Fu et al. 2011). High $\mathrm{SiO}_{2}$ and $\mathrm{Al}_{2} \mathrm{O}_{3}$ elements demonstrate detrital matter source input (Ross and Bustin 2009), which is supported by titanium (Ti) oxide at a level of about 1.04 (Table 4) because Ti coexists within terrestrial remains as well as coarse-grained matter influenced under higher energy conditions (Ross and Bustin 2009; Calvert et al. 1996). In the studied shales, iron oxide $\mathrm{Fe}_{2} \mathrm{O}_{3}$ is the third most prevalent element (averaging $10.10 \mathrm{wt} \%$ ), and it is usually found in association with Fe sulfides (pyrites and marcasite). Its abundance was detected under petrographic observation as pyrite. The major oxide bivariate scatter plots by Herron (1988) are shown in Fig. 9c; this geochemically classified the investigated Orange Basin samples as shales as demonstrated by the various well lithologic descriptions. The average $\mathrm{CaO}$ concentration of 3.92 indicates a calciumrich environment of deposition (marine setting) toward the depocenter of the Orange basin. Phosphorus, another type of major oxide, was also discovered within the block K, Cretaceous shales (Table 4). The observed shales have a moderate phosphorus amount ranging from 0.127 to 0.378 , implying a source of organic matter that is mixed and a reducing sedimentation environment (Shu et al. 2013). Paleoxygenation conditions as determined by biomarker distribution also support this (Table 1). Phosphorus (P) detection in sediments indicates some level of nutrient derivation for biological production (algal growth) under reducing conditions that favor organic matter conservation (Van Cappellen and Ingall 1994; Ingall and Jahnke 1994).

Shales contain trace elements such as $\mathrm{Cr}, \mathrm{V}, \mathrm{Ni}, \mathrm{Co}$, $\mathrm{Mo}, \mathrm{Mn}$, and $\mathrm{Pb}$ with less than 0.1 percent of each element expressed in parts per billion, ppb (Swaine 1990). The origin of organic matter, paleoxygenation during deposition, organic matter preservation, salinities in water,

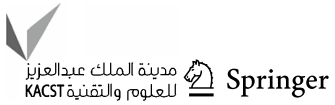




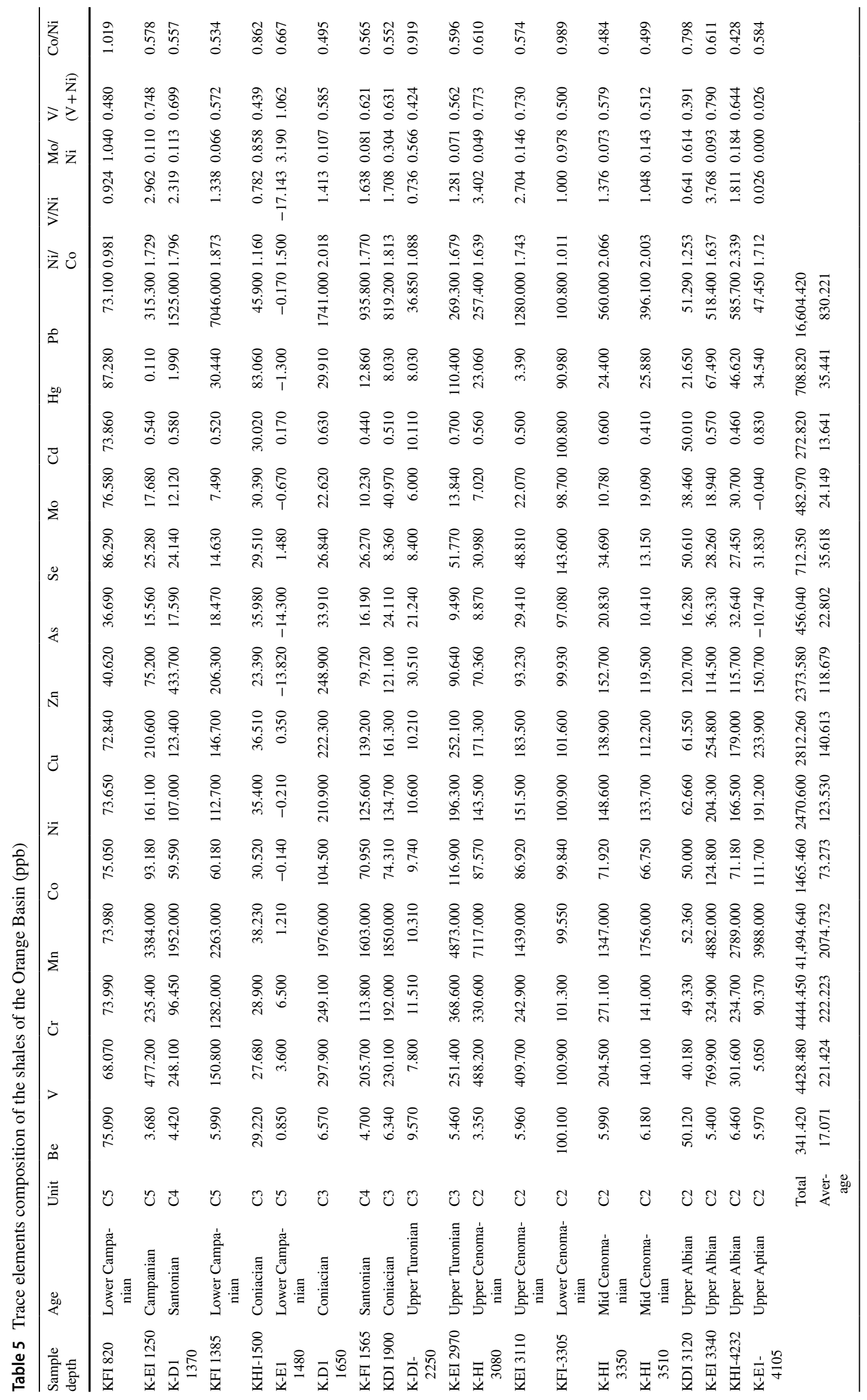


as well as paleoclimates and tectonic restructuring are determined using major and trace elements (Makeen et al. 2015a; Mohialdeen and Raza 2013; Shu et al. 2013; Jia et al. 2013; Moosavirad et al. 2011; Tribovillard et al. 2005). Cretaceous sediments from the Orange Basin were analyzed using ICP-MS to determine the trace element composition of some post-rift rocks. There are 113,169.94 parts per billion of iron ( $\mathrm{Fe})$, followed by aluminum (30,008 ppb), manganese Mn (2,074.73 ppb), and lead $(\mathrm{Pb})(830.22 \mathrm{ppb})$. Among the trace elements found in $\mathrm{OM}$ (biophile), the most abundant is chromium $\mathrm{Cr}$, with a concentration of 222.22 parts per billion ( $\mathrm{ppb}$ ) followed by vanadium (221.42 ppb), then nickel (123.53 ppb), cobalt ( $73.27 \mathrm{ppb})$, and molybdenum (24.15 ppb) are the least. It is common to analyze source rocks for $\mathrm{Ni}$ and $V$ to determine their depositional conditions, oil sources, migration pathways, hydrocarbon maturity, and crude oil classification (Akinlua et al. 2007a, 2007b; Frankenberger et al. 1994; Lewan 1984; Barwise 1990). They are metalloporphyrin complexes that are biophilic in nature incorporated into organic matter or formed during sedimentation (Akinlua et al. 2007a, 2007b; Akinlua et al. 2015). When it comes to identifying oil families, $\mathrm{Ni}$ and $\mathrm{V}$ are excellent choices (Akinlua et al. 2015; Frankenberger et al. 1994). V/Ni concentrations are similar in all examined shales, and they are genetically related, as shown in Fig. 7a. Vanadium concentrations are lower in KF1-820, KD1-2250, KE1-4105, KH1-1500, and KD1-3120 due to migration. Our findings confirmed that all samples came from the same rock which also affirmed (Akinlua et al. 2018; Fig. 7a).

\section{Paleoenvironmental setting during OM sedimentation}

Inorganic geochemical parameters can be used to track physiochemical changes as they occur during sedimentation. Several paleoxygenation sensitive elements, such as
$\mathrm{V}, \mathrm{Ni}, \mathrm{Cu}, \mathrm{Cr}, \mathrm{Mo}$, and $\mathrm{Mn}$, have been found to be good indicators of paleoredox settings (Adebanji et al. 2014; Mc Manus et al. 1999).

Vanadium (V) vs Nickel (Ni) ratio The ratios of redoxsensitive elements like $\mathrm{V}$ and $\mathrm{Ni}$ reveal information about anoxia and deposited matter (Pi et al. 2013; Adebanji et al. 2014). Mostly, sediments contain a comparable amount of these biophile (Lewan 1984). The primary determinants of paleoxygenation conditions during deposition are $\mathrm{V}$ and $\mathrm{Ni}$ (Galarraga et al. 2008; Bechtel et al. 2001). In this manner, $\mathrm{V}$ versus $\mathrm{Ni}, \mathrm{V}$ versus $\mathrm{Cr}$, and $\mathrm{Ni}$ versus Co (Table 5) are sensory indicators of paleoredox settings that differentiate oxic, dysoxic, and anoxic deposits (Galarraga et al. 2008; Ayinla et al. 2017; Hakimi et al. 2015). In a marine environment that ranges from suboxic to anoxic, the amount of vanadium $(\mathrm{V})$ is greater than the amount of nickel $(\mathrm{Ni})(\mathrm{Bar}-$ wise 1990). Vanadium concentrations that are on average higher than nickel concentrations indicate a preponderance of alternating suboxic to anoxic conditions in the area under investigation (Fig. 7b).

Higher $\mathrm{V}$ vs Ni ratios indicate marine OM input, while lower $\mathrm{V}$ versus $\mathrm{Ni}$ ratios indicate terrestrial matters (Akinlua et al. 2018; Galaragga et al. 2008; Akinlua et al. 2007a; Lewan 1984). A greater than one $\mathrm{V}$ versus $\mathrm{Ni}$ ratio indicates a declining marine environment, whereas a ratio of less than one indicates a terrestrial or mixed source (Akinlua et al. 2015; Vander Spuy et al. 2003).

The proven source rock assemblage of Late Aptian age was determined to be terrestrial, with an average V/Ni of 0.026 (Table 5); this contradicts some reports that Aptian shales are anoxic (Hirsch et al. 2009; Paton et al. 2008; vander Spuy et al. 2003; Herbin et al. 1987). Furthermore, 86 percent of its Cenomanian-Turonian source rocks are marine-derived, while only 14 percent show some mixing (Fig. 7b; Table 5). Co/Ni is adapted to distinguish samples from marine and lacustrine environments in order to
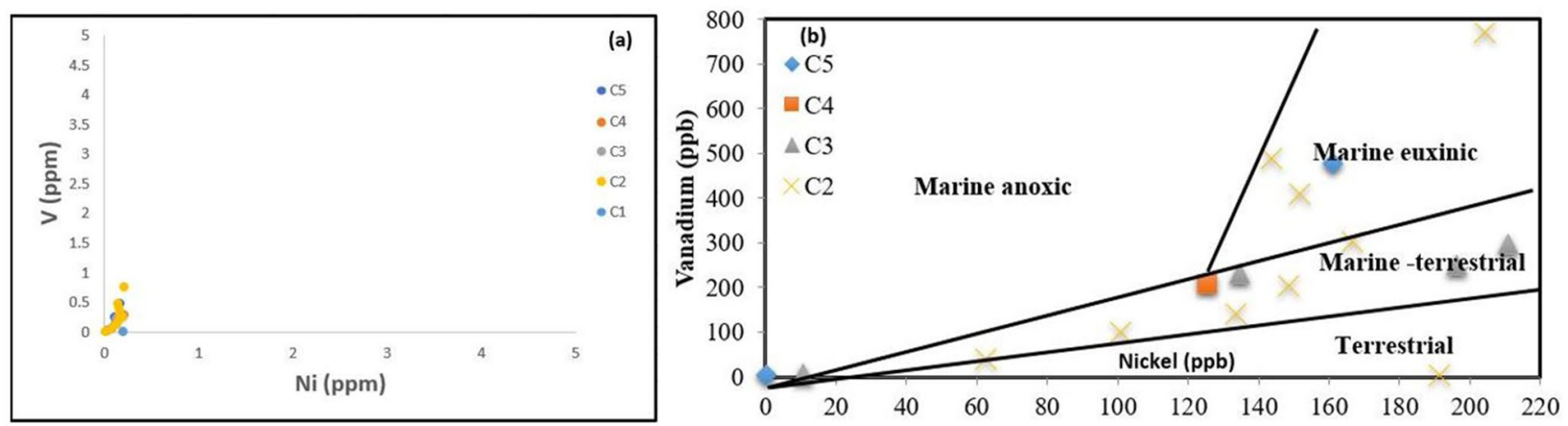

Fig. 7 a: Plot of V against Ni concentrations for all studied samples in the Orange Basin. b: Bivariant plot of vanadium versus nickel showing marine to terrigenous depositional condition for the examined shales (modified after Galarraga et al. 2008)

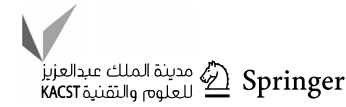


differentiate the source rocks into their appropriate origins. The investigated shales have $\mathrm{Co} / \mathrm{Ni}$ ratios ranging from 0.428 to 1.019 (Table 5). Lacustrine samples have $\mathrm{Co} / \mathrm{Ni}$ values ranging from 0.79 to 1.07 (Akinlua et al. 2018), accounting for up to $25 \%$ of the total rock examined (Table 5). Marinederived source rocks, on the other hand, have a $\mathrm{Co} / \mathrm{Ni}$ ratio of less than 0.79 , accounting for up to $75 \%$ of the sample (Table 5). The V/Ni ratios of some inferred Albian succession source rocks range from 0.641 to 3.768 , while Campanian source rocks have V/Ni ratios from 0.981 to 1.873 . In general, the investigated shaly samples are primarily of marine origin (Fig. 7a, b), with $75 \%$ of the samples being anoxic, and only KF1-820, KH1-1500, KD1-2250, KD13120 , and KE1-4105 having a V/Ni ratio of less than 1 . This suggests that the terrestrial remains in these few samples are insignificant, and that marine organic matter is more prevalent in all the samples.

$\mathrm{V} /(\mathrm{V}+\mathrm{Ni})$ fraction $\mathrm{V} /(\mathrm{V}+\mathrm{Ni})$ values greater than 0.5 were found in $75 \%$ of the tested samples, indicating reduced bottom water conditions, while 25 percent have values less than 0.5 , indicating a dysoxic to anoxic setting of the organic matter (Akinlua et al. 2016). Similarly, V/ $(\mathrm{V}+\mathrm{Ni})$ ratios more than 0.84 , between $0.54-0.82$, and 0.46-0.60, indicates anoxic, eutoxic, and anoxic to dysoxic conditions respectively (Chen et al. 2018; Akinlua et al. 2015). The average $\mathrm{V} /(\mathrm{V}+\mathrm{Ni})$ fraction for all investigated shales is 0.56 , indicating anoxic to dysoxic and mostly anoxic conditions.

\section{Stable isotope of carbon}

Bulk carbon isotope data also distinguishes the varying depositional conditions of organic matter as either marine or mixed matter and depicts the genetic relationship that exists within source rocks (Collisten and Wavrek 1996; Sofer 1984).

According to Sofer (1984), bulk $\delta^{13} \mathrm{C}$ saturates as well as $\delta^{13} \mathrm{C}$ aromatic fractions were also utilized to distinguish rock extracts environment (Fig. 8 a). $\delta^{13} \mathrm{C}$ saturate and $\delta^{13} \mathrm{C}$ aromatic fractions range from -22.29 to -12.24 and -21.38 to -12.4 , respectively, with a mean variable ${ }^{13} \mathrm{C}$ signature ranging from -21.84 to -12.32 . (Table 6). Source rocks from marine versus terrigenous depositional settings were also distinguished using the canonical variable (CV). CV less than 0.47 denotes marine matters, while $\mathrm{CV}$ greater than 0.47 denotes terrestrial plant input (Al-Khafaji et al. 2020; El Diasty et al. 2016; Sofer 1984). The source rocks were derived from the sea, as indicated by the $\mathrm{CV}$ range of -8.83 to -2.72 in the extracts under investigation (Table 6). This is consistent with biomarker interpretations and trace elemental properties.

According to Sofer (1984) plots, these $\delta^{13} \mathrm{C}$ saturated and aromatic fractions were primarily marine-derived (Fig. 8a). As a result, the investigated source rocks are classified as marine source dominated and mixed marine setting with some terrestrial matters. The $\delta^{13} \mathrm{C}$ of marine organic matter ranges from -22 to slightly less than -20 . Mixed marine organic matter following the $\mathrm{C}_{4}$ pathways, on the other hand,

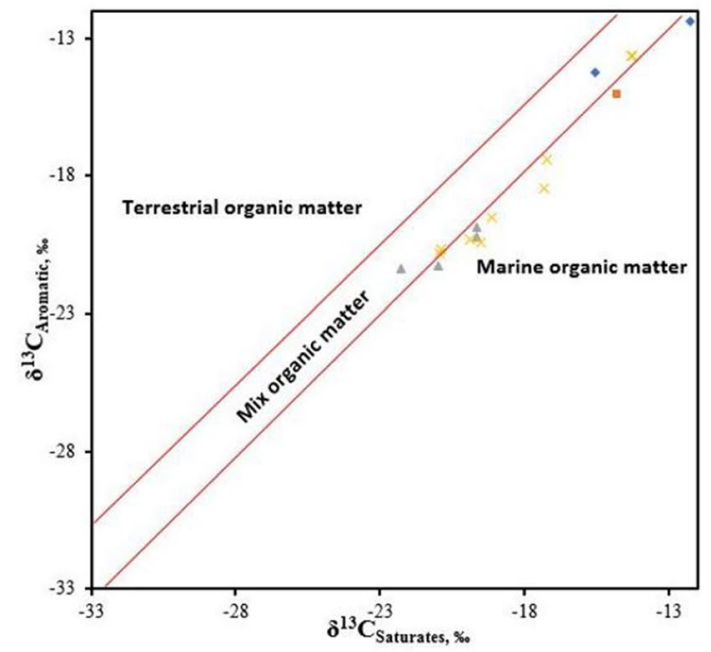

Fig. 8 a: Sofer plot of $\delta^{13} \mathrm{C}$ values for the saturated and aromatic fractions from source rock samples in the Orange basin. All $813 \mathrm{C}$ values are in ppt (\%o) relative to PDB (Sofer 1984). b: Relation of stable iso-

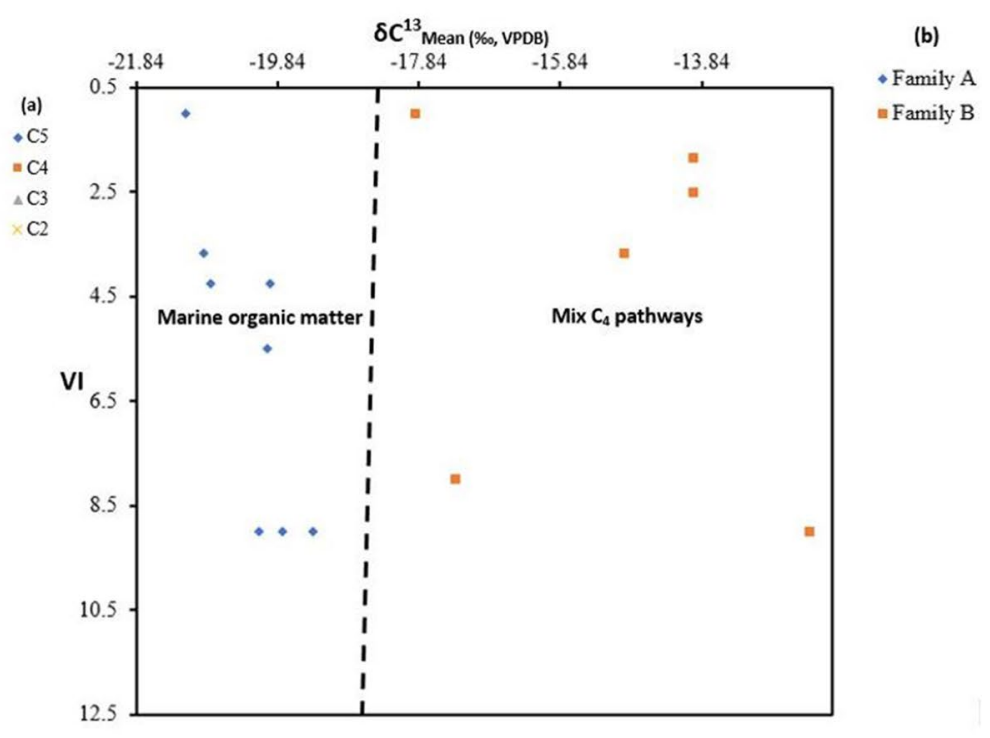

topes of organic carbon $\left(\delta^{13} \mathrm{C}, \%\right)$ and Vegetation Index (VI) for the Orange Basin sediments separated by less negative $\delta^{13} \mathrm{C}$ values and high VI values, respectively 
Table 6 Results for carbon isotopes and vegetative index of selected Orange Basin samples

\begin{tabular}{lllllllll}
\hline Sample name & Age & Unit & $\delta^{13} \mathrm{C}_{\text {ARO }}$ & $\delta^{13} \mathrm{C}_{\mathrm{SAT}}$ & $\delta \mathrm{C}$ Mean & $\mathrm{SD}$ & $\mathrm{CV}$ & $\mathrm{VI}$ \\
\hline KE1-1250 & Campanian & $\mathrm{C} 5$ & -14.22 & -15.54 & -14.88 & 0.933 & -3.902 & 0.000 \\
KE1-1480 & Lower Campanian & $\mathrm{C} 5$ & -12.4 & -12.24 & -12.32 & 0.113 & -8.211 & 9.000 \\
KD1-1650 & Coniacian & $\mathrm{C} 3$ & -20.23 & -19.64 & -19.94 & 0.643 & -6.871 & 4.260 \\
KF1-1565 & Santonian & $\mathrm{C} 4$ & -15.06 & -14.8 & -14.93 & 0.184 & -7.639 & 3.670 \\
KD1-1900 & Coniacian & $\mathrm{C} 3$ & -21.28 & -20.98 & -21.13 & 0.212 & -5.812 & 1.000 \\
KD1-2250 & Upper Turonian & $\mathrm{C} 3$ & -21.38 & -22.29 & -21.84 & 0.643 & -2.720 & 0.000 \\
KE1-2970 & Upper Turonian & $\mathrm{C} 3$ & -19.87 & -19.65 & -19.76 & 0.156 & -6.047 & 9.000 \\
KH1-3080 & Upper Cenomanian & $\mathrm{C} 2$ & -20.81 & -20.95 & -20.88 & 0.099 & -4.845 & 3.670 \\
KE1-3110 & Upper Cenomanian & $\mathrm{C} 2$ & -17.4 & -17.24 & -17.32 & 0.113 & -6.661 & 8.000 \\
KF1-3305 & Lower Cenomanian & $\mathrm{C} 2$ & -13.62 & -14.29 & -13.96 & 0.474 & -5.733 & 2.500 \\
KH1-3350 & Mid Cenomanian & $\mathrm{C} 2$ & -13.62 & -14.29 & -13.96 & 0.474 & -5.733 & 1.840 \\
KH1-3510 & Mid Cenomanian & $\mathrm{C} 2$ & -20.33 & -19.89 & -20.11 & 0.311 & -6.461 & 9.000 \\
KD1-3120 & Upper Albian & $\mathrm{C} 2$ & -20.66 & -20.91 & -20.79 & 0.117 & -4.613 & 4.260 \\
KE1-3340 & Upper Albian & $\mathrm{C} 2$ & -18.47 & -17.32 & -17.9 & 0.813 & -8.834 & 1.000 \\
KH1-4232 & Upper Albian & $\mathrm{C} 2$ & -20.43 & -19.52 & -19.98 & 0.643 & -7.639 & 5.500 \\
KE1-4105 & Upper Aptian & $\mathrm{C} 2$ & -19.52 & -19.14 & -19.33 & 0.269 & -6.560 & 9.000 \\
& & & & & Total & 5.971 & & \\
& & & & & Mean & 0.373 & & \\
\hline
\end{tabular}

$\delta^{13} \mathrm{C}_{\mathrm{SAT}}=$ Stable carbon isotopic composition $(\% \circ)$ of the saturated $\mathrm{HC}$ fraction; $\delta^{13} \mathrm{C}_{\mathrm{ARO}}=$ Stable carbon isotopic composition $(\%)$ of the aromatic $\mathrm{HC}$ fraction; Canonical variable $(\mathrm{CV})=-2.53 \delta^{13} \mathrm{C}_{\mathrm{SAT}}+2.22$ $\delta^{13} \mathrm{C}_{\mathrm{ARO}}-11.65$; VI $=$ Vegetation index ranges from slightly below -12 to up to -18 . (Fig. 8a, b). As a result, approximately 57 percent of the samples examined are marine-influenced, while 43 percent are mixed derived via the $\mathrm{C}_{4}$ path. This is also consistent with inorganic geochemistry findings.

\section{Correlation analysis using statistics}

For the purpose of describing the geochemical processes that affected the studied shales, the geochemical data was subjected to a Pearson correlation analysis. The Pearson correlation matrix for the investigated shales is shown in Table 7. Except for $\mathrm{Al}_{2} \mathrm{O}_{3}$ and $\mathrm{K}_{2} \mathrm{O}, \mathrm{SiO}_{2}$ having negative correlation with all the major oxides, as shown by the matrix $\left(\mathrm{Fe}_{2} \mathrm{O}_{3}, \mathrm{CaO}, \mathrm{MgO}, \mathrm{MnO}, \mathrm{Na}_{2} \mathrm{O}, \mathrm{TiO}_{2}\right)$. Quartz is the primary source of silica because $\mathrm{SiO}_{2}$ has a negative correlation with all the major oxides (Abubakar et al. 2021, 2019; Sonfack et al. 2021; Ahmad and Chandra 2013). The fact that $\mathrm{SiO}_{2}$ is positively correlated with $\mathrm{Al}_{2} \mathrm{O}_{3}$ and $\mathrm{K}_{2} \mathrm{O}$ indicates that clay mineral is a secondary source of silica (Nagarajan et al. 2017). $\mathrm{Al}_{2} \mathrm{O}_{3}$ has a significant negative correlation with $\mathrm{Fe}_{2} \mathrm{O}_{3}, \mathrm{CaO}, \mathrm{MgO}, \mathrm{MnO}, \mathrm{Na}_{2} \mathrm{O}, \mathrm{TiO}_{2}$, and $\mathrm{P}_{2} \mathrm{O}_{5}$, indicating that it is dissociated from clay minerals (Abubakar et al. 2021). The decomposition of K-feldspars could be a source of kaolin minerals, based on the strong positive relationship between $\mathrm{Al}_{2} \mathrm{O}_{3}$ and $\mathrm{K}_{2} \mathrm{O}$ (Abubakar et al. 2019). $\mathrm{Fe}_{2} \mathrm{O}_{3}$ exhibits a strong positive relationship with $\mathrm{CaO}, \mathrm{MgO}$,
$\mathrm{MnO}, \mathrm{Na}_{2} \mathrm{O}, \mathrm{TiO}_{2}$, and $\mathrm{P}_{2} \mathrm{O}_{5}$, implying that these elements are associated with heavy mineral fractions (Sonfack et al. 2021). $\mathrm{CaO}$ has a good association with $\mathrm{MgO}, \mathrm{MnO}, \mathrm{Na}_{2} \mathrm{O}$, $\mathrm{TiO}_{2}$, and $\mathrm{P}_{2} \mathrm{O}_{5}$, indicating that it is related to carbonate minerals (Nagarajan et al. 2017). In contrast to other major oxides, $\mathrm{CaO}$ has a negative correlation, particularly $\mathrm{SiO}_{2}$, $\mathrm{Al}_{2} \mathrm{O}_{3}, \mathrm{Fe}_{2} \mathrm{O}_{3}$, and $\mathrm{K}_{2} \mathrm{O}$, signifying that carbonate minerals are the primary source of $\mathrm{Ca}$ (calcite), with no influence from detrital sources (Bessa et al. 2021). As indicated by K-feldspar and plagioclase products in the studied shales, chemical weathering is responsible for the negative correlation between both $\mathrm{K}_{2} \mathrm{O}$ and $\mathrm{Na}_{2} \mathrm{O}$ (Nagarajan et al. 2017).

\section{Distribution of silica content}

The mineralogical content of shales, particularly the calcific content, as well as the quartz content, regulates fracture growth (Ding et al. 2012; Jarvie 2012). These shales range from 51.01 to 63.31 percent silica content (Table 4), with the Upper Turonian KE1-2970 having the highest silica content. $\mathrm{Al}_{2} \mathrm{O}_{3}$ has a remarkable range of $12.33-17.85$ percent, whereas $\mathrm{CaO}$ is generally low, ranging from 1.29 to $11.81 \%$. This shales' mineralogy is silica dominant, as determined by radiolarian and planktonic tests (Davies 1970). As a result of the presence of reasonable clastic (silica and some carbonates) in the investigated shales, it becomes hard and brittle, allowing it to possibly expel hydrocarbons.

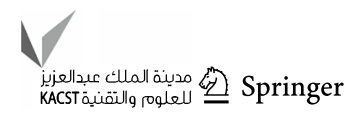




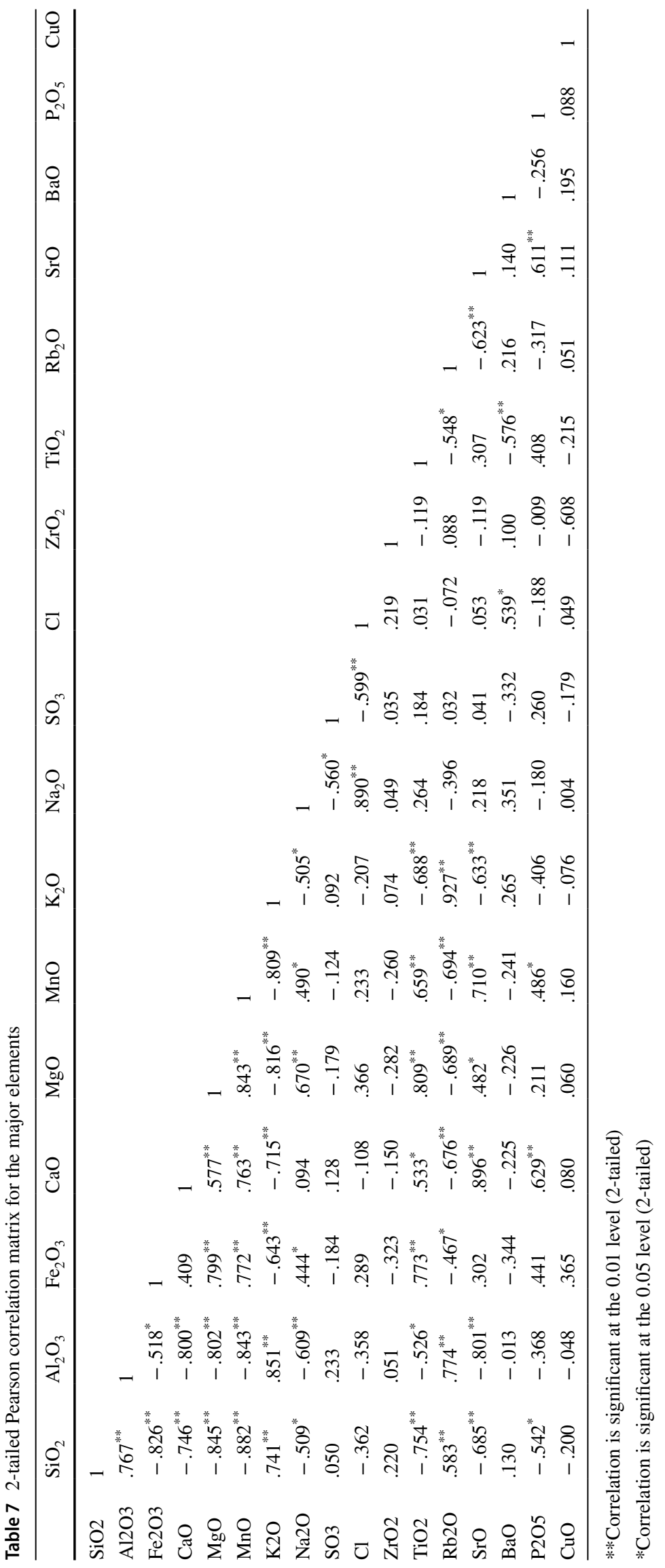




\section{Provenance}

Using the obtained $\mathrm{SiO}_{2}$, geochemical proxies from the examined shales determine the origin of sediments, which can be grouped based on mafic, intermediate, and feldspar content (Armstrong-Altrin 2009). All evaluated samples fall within the compositional field of intermediate igneous rocks, as shown by the plot $\mathrm{Al}_{2} \mathrm{O}_{3} / \mathrm{TiO}_{2}$ vs $\mathrm{SiO}_{2}$ in Fig. 9a. Similarly, $\mathrm{K}_{2} \mathrm{O} / \mathrm{Al}_{2} \mathrm{O}_{3}$ ratios can be used to identify the parent matter of muddy rocks. Samples with a $\mathrm{K}_{2} \mathrm{O}_{\mathrm{Al}} \mathrm{Al}_{2} \mathrm{O}_{3}$ ratio of less than 0.4 show little alkali feldspar, whereas shales with values greater than 0.5 show abundant alkali feldspar in proportion to some other minerals within the shales (Cox et al. 1995). The presence of a small amount of $\mathrm{K}_{2} \mathrm{O} / \mathrm{Al}_{2} \mathrm{O}_{3}$ values $(0.126-0.191)$ in the examined shales indicates a low granitic composition in the source area. Furthermore, $\mathrm{Al}_{2} \mathrm{O}_{3} /$ $\mathrm{TiO}_{2}$ accurately depicts the genesis of source rock (Andersson et al. 2004; Hayashi et al. 1997; Garcia et al. 1994). Whenever $\mathrm{Al}_{2} \mathrm{O}_{3} / \mathrm{TiO}_{2}$ ratio is 3-8wt percent, it refers to mafic igneous rock, $8-21 \mathrm{wt}$ percent denotes an intermediate source origin, and $21-70 \mathrm{wt}$ percent denotes feldspardominated igneous rock. For the shale samples examined, the $\mathrm{Al}_{2} \mathrm{O}_{3} / \mathrm{TiO}_{2}$ ratios ranged from 9.998 to 20.311 (Table 4), indicating that the sediments were formed by intermediate igneous rocks (Fig. 9a). It is worth noting that all the computations and illustrative plots performed confirm the origins of Orange Basin shales from Intermediate Igneous rocks, as $\mathrm{Zr} / \mathrm{Ti}$ plots (Fig. 9b). The major oxide bivariate scatter plots by Herron (1988) are shown in Fig. 9c; geochemically classifying the investigated Orange Basin samples as shales as observed on hand specimen and some lithologic descriptions. Similarly, the major elements discrimination diagram (Fig. 9d) plotted the shales within the intermediate igneous field.

\section{Paleoweathering conditions and sediment maturity}

Alkali and alkali earth metal concentrations in rocks determine the degree of weathering in sediments (Nesbitt and Young 1982). Weathering indices are calculated using the following formulas: i) The chemical index of alterations (CIA) and ii) chemical variability index (ICV) as initiated by Nesbitt and Young (1982).
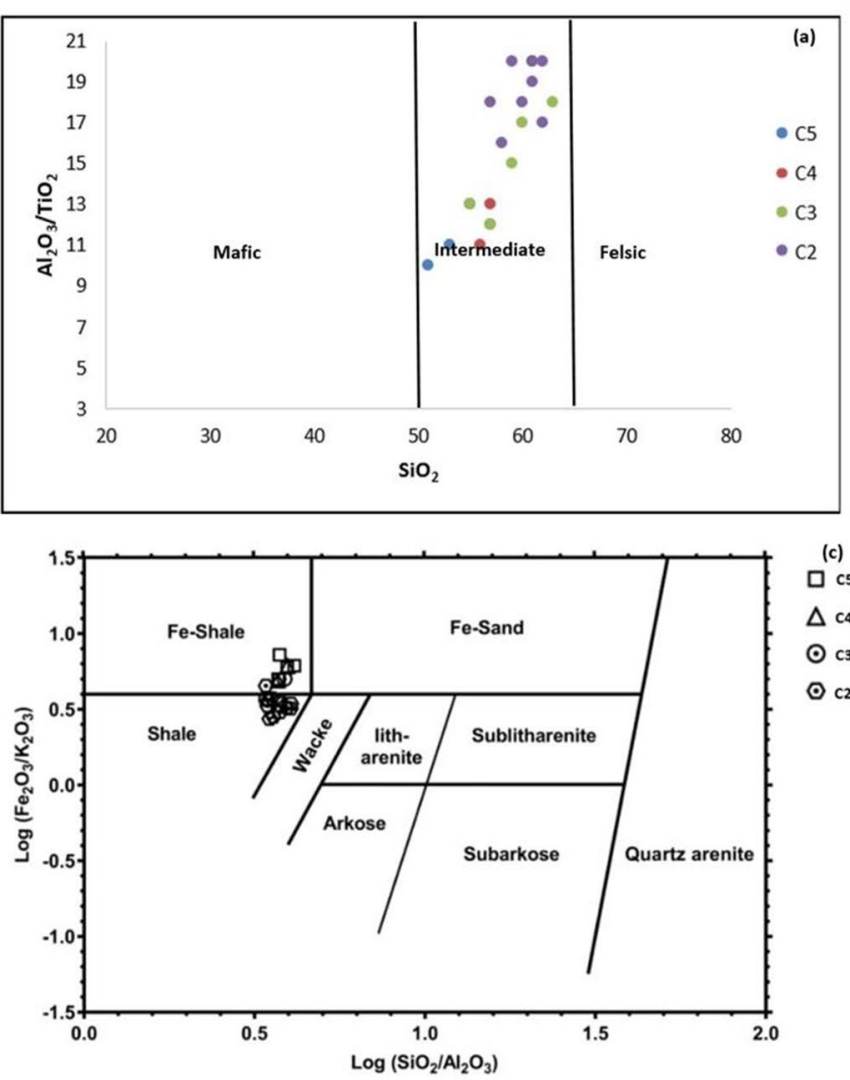

Fig. 9 a: $\mathrm{Al}_{2} \mathrm{O}_{3} / \mathrm{TiO}_{2}$ vs $\mathrm{SiO}_{2}$ plot for the Orange Basin sediments. b: Scatter diagram of Zircon against Titanium oxides of the shales in Orange Basin (after Hayashi et al. 1997). c: Geochemical classifica-

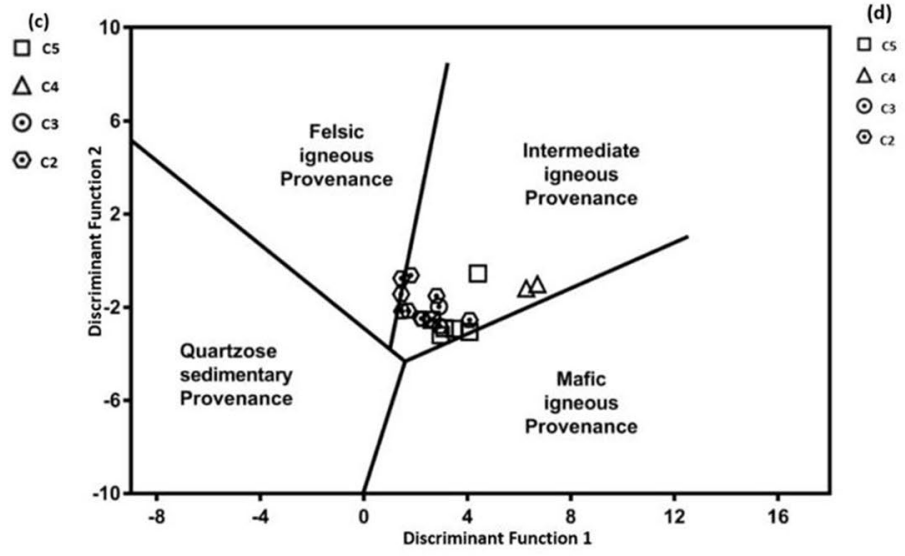

tion of the shales, Orange Basin (after Herron, 1988). d: Discriminant function figure of the major elements showing provenance of the shales (Roser and Korsch 1988) 
$\mathrm{Rb}_{2} \mathrm{O} / \mathrm{SrO}$ and $\mathrm{SiO}_{2} / \mathrm{Al}_{2} \mathrm{O}_{3}$ ratios were also calculated to assess the textural and compositional maturity of the Orange Basin shale.

$$
\mathrm{ICV}=\left(\mathrm{K}_{2} \mathrm{O}+\mathrm{Fe}_{2} \mathrm{O} 3+\mathrm{Na}_{2} \mathrm{O}+\mathrm{CaO}+\mathrm{MgO}+\mathrm{MnO}\right) /
$$
$\mathrm{Al}_{2} \mathrm{O}_{3}$.

$$
\mathrm{CIA}=\left(\mathrm{Al}_{2} \mathrm{O}_{3} /\left[\mathrm{Al}_{2} \mathrm{O}_{3}+\mathrm{CaO}+\mathrm{K}_{2} \mathrm{O}+\mathrm{Na}_{2} \mathrm{O}\right]\right) * 100(\mathrm{Nes}-
$$
bitt and Young 1982).

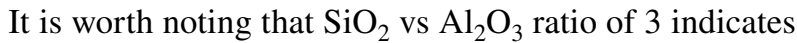
basic igneous rocks, while a ratio of 5 reveals acidic rocks (Cox et al. 1995). In clastic sediments, these ratios are higher than 5, indicating high maturity, while below the $\mathrm{SiO}_{2} / \mathrm{Al}_{2} \mathrm{O}_{3}$ ratio indicates immaturity (Abubakar et al. 2021; Hernandez-Hinojosa et al. 2018; Cox et al. 1995). The calculated $\mathrm{SiO}_{2} / \mathrm{Al}_{2} \mathrm{O}_{3}$ ratios range from 3.41 to 4.14 , indicating that the investigated sediments are texturally immature (Table 4).

Similarly, an average ICV index greater than 0.85 denotes a typical rock-forming mineral, while less than 0.85 denotes alteration product. Sediment ICV values is from 1.07 to 2.56 , with an average of 1.55 , signifying weathering activities within the study area (Table 4). Furthermore, ICV versus CIA (Fig. 10) demonstrates that all the original matter analyzed shales plotted above the Post Archean Australia Shales (PAAS) ICV index of about 0.85 , indicating immaturity in the composition as well as relatively mild weathering of original source materials (Hernández-Hinojosa et al. 2018).

Another calculation that explains the level of weathering within the source area is the CIA (Nesbitt and Young 1982). Thus, calculated CIA average value is 64.72, oscillating between 45.93 and 74.41 (Table 4 ), attesting the weathering effect around the parent aggregates (Fig. 10).

Because $\mathrm{Sr}^{2+}$ easily leaches out of terrestrial inputs, the $\mathrm{Rb}_{2} \mathrm{O} / \mathrm{SrO}$ fraction is also used to investigate weathering processes (McLennan et al. 1993). The examined shales have mean $\mathrm{Rb}^{+} / \mathrm{Sr}^{2+}$ values ranging from 2.10 to
0.32 above the mean upper continental crust (UCC) value of 0.32 , implying some level of weathering activity, as demonstrated by other computations.

\section{Paleosalinity}

$\mathrm{Sr}^{2+}$ and $\mathrm{Ba}$ are useful paleosalinity index metals (Wang 1996; Deng and Qian 1993; Liu et al. 1984). They have been significantly modified to depict both seawater and freshwater imprints (Moradi et al. 2016). A high $\mathrm{Sr} / \mathrm{Ba}$ ratio indicates a high level of salinity, whereas a low $\mathrm{Sr} / \mathrm{Ba}$ ratio indicates a low level of salinity (Deng and Qian 1993).

Less than 0.20 $\mathrm{Sr} / \mathrm{Ba}$ ratio indicates freshwater, and more than 0.5 indicates marine water influence $(\mathrm{Li}$ et al. 2020; Wei and Algeo 2020). Values ranging from 0.2 to 0.5 indicate a brackish water environment, but caution should be exercised when generalizing the $\mathrm{Sr} / \mathrm{Ba}$ ratio. The $\mathrm{Sr} / \mathrm{Ba}$ ratio in the investigated shales ranges between 0.032 and 1.160 (Table 4). In general, 40 percent of the studied shales were derived from seawater, 25 percent from brackish waters, and 35 percent from freshwater settings. The V/Ni vs Sr/Ba cross-plots (Fig. 11b) illustrate relatively low-to-moderate saline stratification as compatible with the varying marine to freshwater influences (0.032-1.160). Due to the low gammacerane index (Fig. 11a; Table 2), stratification during deposition of most samples was minimal signifying low salinity (Peters et al. 2005; Sinninghe Damste et al. 1995).

\section{Paleovegetation and paleoclimatic evolution}

Proxy wax $\left(P_{\text {wax }}\right)$, proxy aqueous $\left(P_{\mathrm{aq}}\right)$, and average chain length (ACL) biomarker identifiers are best suited for
Fig. 10 ICV vs CIA plots showing the immaturity and magnitude of weathering of the Orange Basin sediments (after Long et al. 2011)

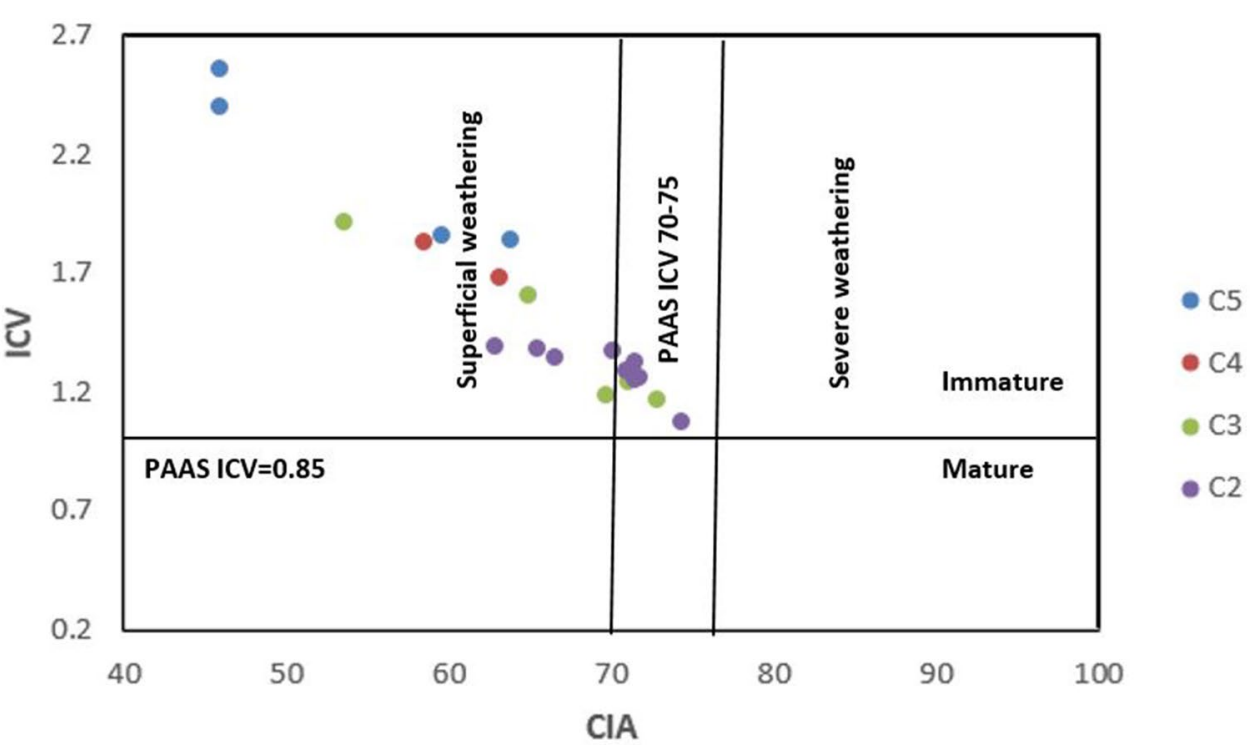

لو مدينة الملك عبدالعزيز KACST 

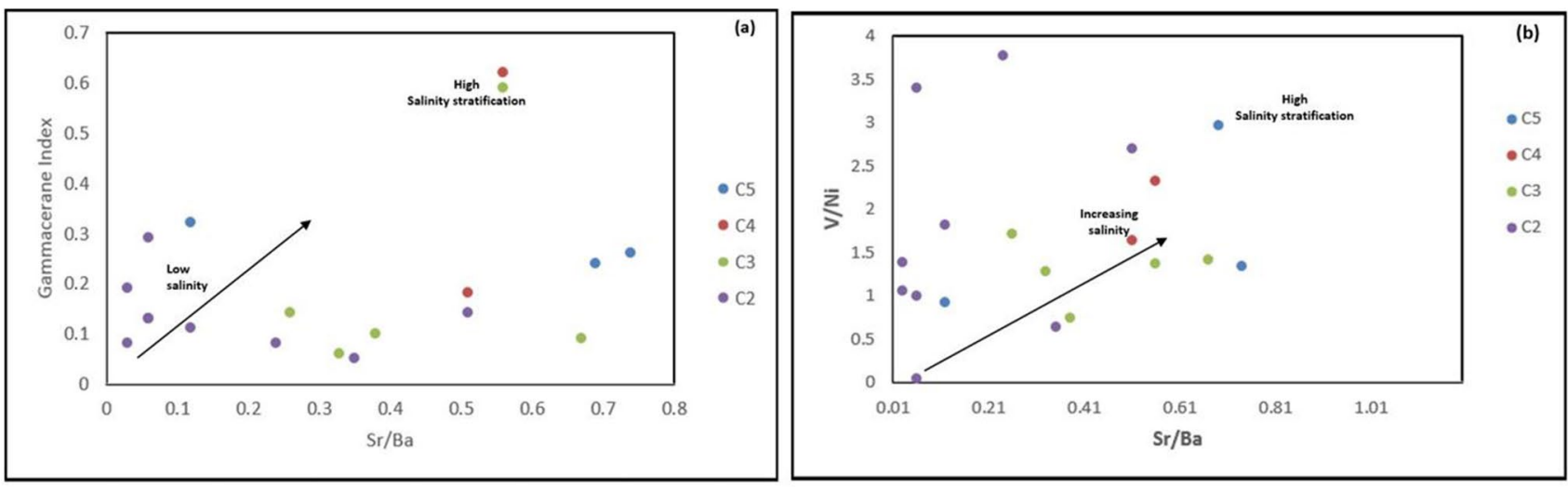

Fig. 11 a: Gammacerane index versus $\mathrm{Sr} / \mathrm{Ba}$ ratio.b: V/Ni ratio versus $\mathrm{Sr} / \mathrm{Ba}$ for the shaly sediments of the Orange Basin, South Africa (adopted after Jia et al. 2013)

reconstructing paleovegetation and paleoclimates (He et al. 2019; Ortiz et al. 2013). Pwax deals with the concentration of waxy hydrocarbons derived from higher plants (Zheng et al. 2007). These proxies, specifically $n-C_{23} /\left(n-C_{27}+n-C_{31}\right)$ ratios, measure the comparable amount of Sphagnum species to terrigenous remains to represent the water level within sediments (Andersson et al. 2011). According to $\mathrm{He}$ et al. 2019, $n-C_{23} /\left(n-C_{27}+n-C_{31}\right)$ value greater than 0.2 indicates a predominance of sphagnum in a wet environment, as demonstrated by ranges of the analyzed sediments from 0.71 to 5.60. This analysis is supported by Paq values (Table 1), which indicate the contributions of emergent and submerged plants, as well as $\mathrm{P}_{\text {wax }}$ values. A humid environment with abundant $\mathrm{C}_{27} \mathrm{n}$-alkanes promotes the growth of woody vegetative cover. Herbaceous remains, on the other hand, are rich in $\mathrm{n}-\mathrm{C}_{31}$ and thrive in a dry, warm environment. Even though we are dealing with the dominantly marineinfluenced matter as proved by low terrigenous aquatic ratio ranging between 0.07 and 2 (Table 1). The relative number of $\mathrm{nC}_{27}, \mathrm{nC}_{29}, \mathrm{nC}_{31}$ alkanes is adapted to categorize terrigenous remains as grasses dominated or predominantly from deciduous trees or conifers. Abundant $\% \mathrm{C}_{31}$ shows grasses input (Maffei 1996), while the preponderance of $\% \mathrm{C}_{27}$ shows more deciduous trees (Oritz et al. 2010). The predominance of conifers is increasing in $\mathrm{n}-\mathrm{C}_{29}$ (Schwark et al. 2002). Woody vegetation is associated with a humid climate that contains more $\mathrm{C}_{27}$ alkanes, while herb shrubs thrive in the warm, droughty season (Vegas et al. 2010). A tri-plot of n-alkane $\% \mathrm{C}_{27}, \% \mathrm{C}_{29}$, and $\% \mathrm{C}_{31}$ shows a predominance of $\mathrm{C}_{27}$ n-alkanes (Fig. 12), confirming humid paleovegetative climatic cover. It was determined by Lopez-Dias et al. (2013) that woody and herbaceous higher plants contributed to the paleoclimate in different proportions by adapting to the $n-C_{27} / n-C_{31}$ ratio. $n-C_{27} / n-C_{31}$ ratio ranges between 2.00 and 14.00 (Table 1), which corresponds to our more humid climatic phase of deciduous tree growth.

Terrigenous input and paleoclimatic settings are constructed using a variety of major and trace elements (Liang et al. 2018; Li et al. 2020). Paleoclimate reconstruction in the Orange Basin is largely based on C-values. This shows that warm, humid sediments have higher $\mathrm{Fe}, \mathrm{Mn}, \mathrm{Ni}, \mathrm{Cr}, \mathrm{V}$, and Co concentration, while arid emplaced deposits are blessed with higher $\mathrm{Ca}, \mathrm{Mg}, \mathrm{Sr}$, Ba elements. $C$-value $=\Sigma(\mathrm{Fe}+\mathrm{Mn}+\mathrm{Ni}+\mathrm{Cr}+\mathrm{V}+\mathrm{Co}) / \Sigma$ $(\mathrm{Ca}+\mathrm{Mg}+\mathrm{Sr}+\mathrm{Ba}+\mathrm{K}+\mathrm{Na})$, part per million ( $\mathrm{Li}$ et al. 2020). This means the greater the $C$-values, the more humid while lower $\mathrm{C}$-values connotes arid paleoclimate. $C$-value above 0.8 shows humid nature, $0.6-0.8$ signifies a semihumid climate, and 0.4-0.6 connote semiarid to semi-humid paleoclimatic settings. On the other hand, semiarid paleoclimates have $C$-values that spans from 0.2 to 0.4 (Cao et al. 2012; Qui et al. 2015), and below 0.2 refers to arid paleoclimates. The shales of the Orange basin have $\mathrm{C}$-values ranging from 0.60 to 1.34 (Table 4) signifying semi-humid to humid paleoclimatic conditions. The $\mathrm{Sr} / \mathrm{Cu}$ values were adopted to depict the paleoclimatic setting when terrestrial organofacies were emplaced (Liu and Zhou 2007; Moradi et al. 2016; Li et al. 2020). Low $\mathrm{Sr} / \mathrm{Cu}$ ratios are associated with humid climates, also, the higher the values, the more aridity it is (Liu \& Zhou, 2007). Sr vs $\mathrm{Cu}$ index ranging from 1.5 to 5 represents warm-humid climate, whereas ratios above 5 connote hot, dry climatic conditions (Han et al. 2020). The investigated shaly sediments are within the warm, humid climatic condition as the $\mathrm{Sr} / \mathrm{Cu}$ ratio is averagely up to 1.63 , ranging from 0.857 to 2.737 (Table 4). The inorganic calculations on the paleoclimate settings of the Orange Basin are therefore tied to the biomarker proxies. 
Fig. 12 Ternary plot of $\% \mathrm{C}_{27}$, $\% \mathrm{C}_{29}$ and $\% \mathrm{C}_{31}$ n-alkane suggesting dominantly humid paleo-vegetative climate

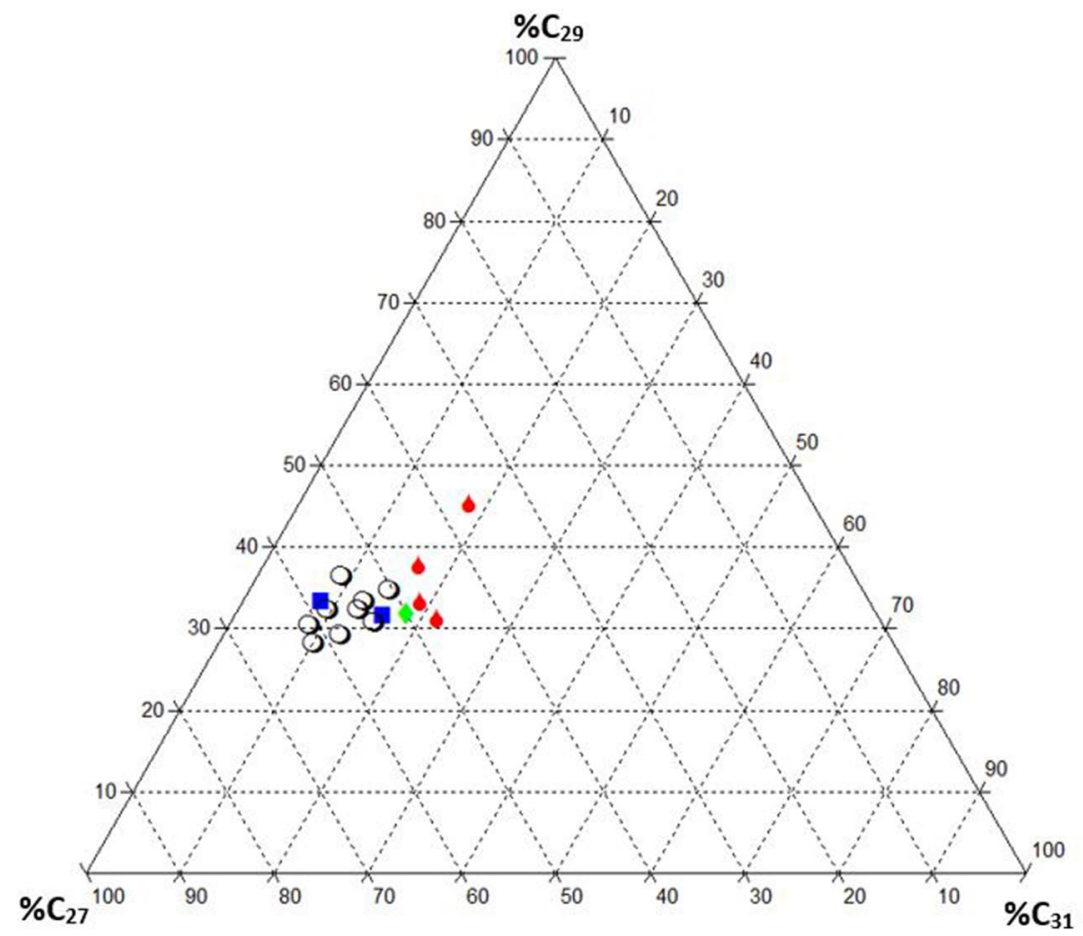

Using a stable isotope of carbon as a determinant of sediment settings and paleoclimate is hard to decrypt. $\delta^{13} \mathrm{C}$ variability is predominant than observed between macerals of the exact succession; as such, these differences are not from changes in organic matter composition only (Jingjing et al. 2020). A good correlation of maceral indices exists between $\delta^{13} \mathrm{C}$ and the vegetation index. The vegetation index (VI) computes the maceral constituent ratio (Calder et al. 1991), which is supported by $\delta^{13} \mathrm{C}$ and other data (Table 6; Fig. 8b).

Therefore, $\mathrm{VI}=(\mathrm{TEL}+\mathrm{FUS}+\mathrm{SFU}+\mathrm{SUB}+\mathrm{RES}) /(\mathrm{DE}$ $\mathrm{N}+\mathrm{INT}+\mathrm{ALG}+\mathrm{LPD}+\mathrm{SPO}+\mathrm{CUT})$.

$\mathrm{TEL}=$ tellocollinites, FUS = fusinite, $\mathrm{SFU}=$ semifusinite, $\mathrm{SUB}=$ suberinite, $\mathrm{RES}=$ resinite, $\mathrm{DEN}=$ densinite, $\mathrm{INT}=$ inertodetrinite, $\mathrm{ALG}=$ alginite, $\mathrm{LPD}=$ liptodetrinite, $\mathrm{SPO}=$ sporinite , and CUT $=$ cutinite .

Thus, VI (Jingjing et al. 2020) adequately depicts the amount of preserved tissues, degraded tissues, and particulate organic matters present. Almost all less negative $\delta^{13} \mathrm{C}$ values go with the intermediate VI values (Table 6; Fig. 8b). Higher VI connotes woody vegetation, favoring drier and shallow water table (Calder et al. 1991; Calder 1993; Jingjing et al. 2020). Low VI, on the other hand, may indicate a wetter environment, resulting in larger, more microbially diverse herbaceous plants. Therefore, VI and the mean $\delta^{13} \mathrm{C}$ association corroborate that there were fluctuating semidry and wet intervals in the time of Orange Basin sediment amassment (Table 6).

\section{Tectonic framework restructuring}

The tectonic setting in the Orange basin is well-understood via inorganic major and trace element bivariate plots. Plate tectonics influences the rock chemistry (Peters et al. 2005; Makeen et al. 2015a). Using bulk elemental analyses, bivariate plots of $\mathrm{K}_{2} \mathrm{O} / \mathrm{Na}_{2} \mathrm{O}$ vs $\mathrm{SiO}_{2}$ were used to reconstruct the tectonic setting of the Orange basin (Roser and Korsch, 1986). The concentration of $\mathrm{K}_{2} \mathrm{O} / \mathrm{Na}_{2} \mathrm{O}$ and $\mathrm{SiO}_{2}$ increases from oceanic island arc settings through active continental boundary settings into passive margins. Most of the investigated shales fall within the passive continental margin, with only two samples falling within the active margin (Fig. 13a). Generally, three types of tectonic settings, according to Verma and Amstrong-Altrin (2013): island or continental arc, continental rift, and collisional configuration. Figure $13 \mathrm{~b}$ depicts plots within the continental rift indicating the Orange basin shales as a byproduct of the rifted passive margin. A similar tectonic episode is thought to have occurred in West and Central Africa at about the same time as the South American plate opened during the Cretaceous (Genik 1992). The opening of the Atlantic Ocean during the Early Cretaceous Period was the primary cause of the separation of the West African plates (Guiraud and Maurin 1992). 


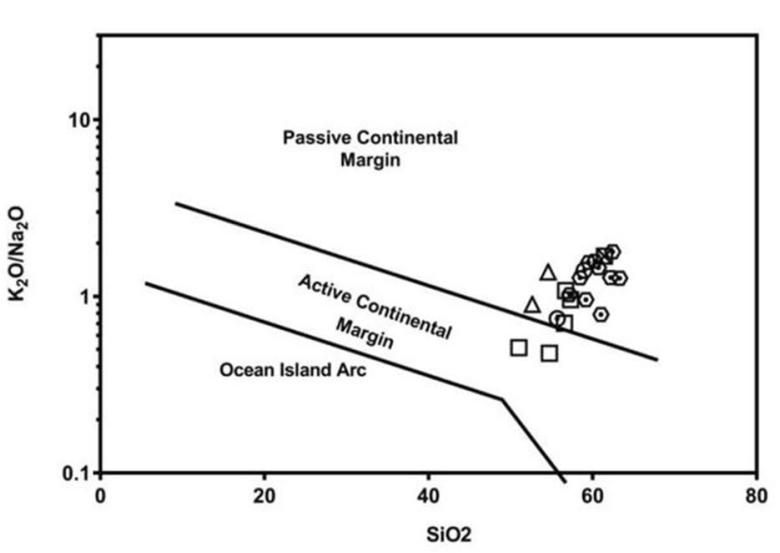

Fig. 13 a: Bivariate plots of $\mathrm{K}_{2} \mathrm{O} / \mathrm{Na}_{2} \mathrm{O}$ versus $\mathrm{SiO}_{2}$ showing the tectonic setting of Orange Basin based on investigated shales (adapted afterRoser and Korsch 1986). b: Tectonic setting based on discrimi-

\section{Conclusions}

The depositional environment, lithotype, age and thermal maturity of Cretaceous post-rift sediments from the Orange Basin were revealed by molecular, bulk geochemical, and elemental characterization. Some of the findings are as follows:

I. The unimodal pattern of n-alkane, as well as its components such as $\mathrm{Pr}$ vs $\mathrm{Ph}, \mathrm{Pr} / \mathrm{nC}_{17}$ versus $\mathrm{Ph} / \mathrm{nC}_{18}$ cross-plot, $\mathrm{Pr} / \mathrm{Ph}$ vs $\mathrm{C}_{29} \mathrm{R} / \mathrm{C}_{27} \mathrm{R}, \mathrm{Pr}$ vs $\mathrm{Ph}$, and $\mathrm{C}_{27} /$ $\left(\mathrm{C}_{27}+\mathrm{C}_{29}\right) \mathrm{R}$, confirms the accumulation of the studied lithofacies in a coastal anoxic environment. To determine the origin of source rock samples, a biomarker with structural similarities to precursor kerogen and biodegradation resistance was used. Based on aliphatic and aromatic compounds, this method revealed that all samples have the same structure. As a result, all the samples were obtained from the same source.

II. Biomarker finger printing is consistent with inorganic trace elements because samples are primarily from the same source rock from the same family of rocks and derived under anoxic to dysoxic conditions. This is supported by a $\mathrm{Pr} / \mathrm{Ph}$ ratio of less than one, a homohopane distribution, and a V/ $(\mathrm{V}+\mathrm{Ni})$ ratio. Geochemically, the $\mathrm{G} / \mathrm{C}_{30}$ value refl ects that the source rock must have been accumul ated under reduced conditions, with the sedimentary column consisting of a stratified aqueous column.

III. A wide range of maturation is evident in the samples examined, ranging from immature to late oil genera-

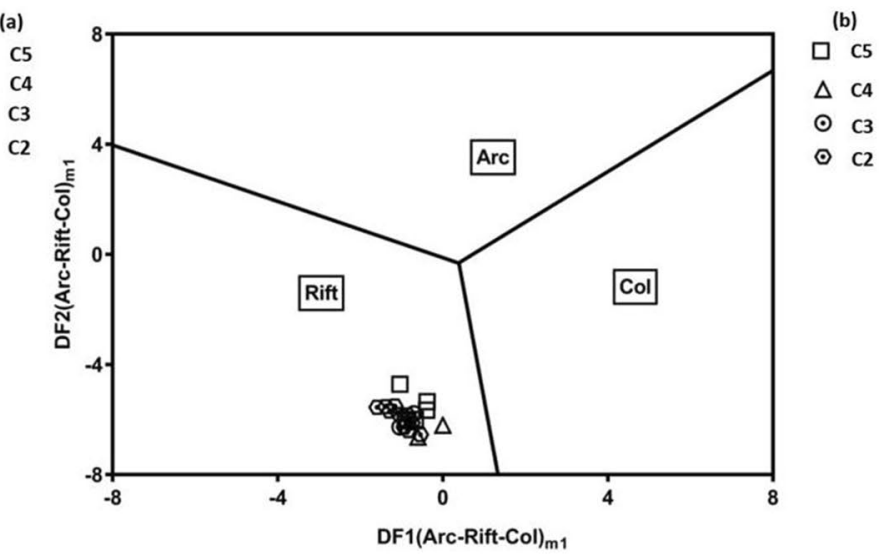

nant function for the shales of the Orange Basin (after Verma and Armstrong-Altrin 2013)

tion. Thermal maturity parameters adapted included $\mathrm{C}_{32} 22 \mathrm{~S} /(22 \mathrm{~S}+22 \mathrm{R}), \mathrm{C}_{29} \alpha \alpha \alpha \mathrm{S} /(20 \mathrm{~S}+20 \mathrm{R}), \mathrm{M}_{30} / \mathrm{C}_{30}$ ratio, $\mathrm{C}_{29}$ diasterane $/ 29 \alpha \alpha \alpha \mathrm{R}$ and the methylphenanthrene index calculated vitrinite reflectance (VRc percent) and measured $\mathrm{VR}_{\mathrm{O}}$ percent), with $50 \%$ of examined samples showing peak oil window (0.6760.899).

IV. Inorganic trace findings, together with molecular geochemical cross-plots, isotopic $\delta^{13} \mathrm{C}$ saturate, and $\delta^{13} \mathrm{C}$ aromatic cross-plots, confirm the marine genetic origins of organic matters with few mixed materials.

V. The majority of the less negative $\delta^{13} \mathrm{C}$ values are associated with woody vegetation that thrives in lower standing water tables and less wet climatic conditions. Thus, VI and the mean $\delta^{13} \mathrm{C}$ association support the existence of fluctuating dry and wet intervals during the time of Orange Basin sediment accumulation.

VI. Source rock inputs were differentiated by adapting Paq, TAR, and total amounts of $n-C_{27}, n-C_{29}$, and $\mathrm{n}-\mathrm{C}_{31}$. A long-chain $\mathrm{n}$-alkane in a variable form, particularly $n-\mathrm{C}_{27}$, demonstrates diversity in vegetation and can be used to reconstruct paleoenvironmental evolution; in the dry season, grasses grow, while trees multiply in the rainy season.

VII. Inorganic computations on the paleoclimatic condition of the Orange Basin agree with biomarker proxies and isotopic studies confirming semi-humid to humid paleoclimatic conditions.

VIII. In terms of textural and compositional maturity, shale samples were classified as immature. Tectonic setting discriminant function diagrams showed that the continental rift's marginal zone was passive. According to this interpretation, the tectonic setting is consist- 
ent with the Cretaceous event of West and Central Africa, which separated the South American plate from the West African plate, resulting in the opening of the South Atlantic Ocean and the creation of the Orange Basin.

\begin{abstract}
Acknowledgements Usmanu Danfodiyo University in Sokoto, Nigeria, and the Tertiary Education Trust Fund are thanked for providing the first author with a study leave and a $\mathrm{PhD}$ fellowship at the University of Malaya in Malaysia. The authors gratefully acknowledge a research grant from the University of Malaya (GPF019B-2018; IF064-2019). The authors would also like to thank the Petroleum Agency of South Africa (PASA) for supplying the cutting samples. We are grateful to Mr. Zamri and Mr. Aliff for their assistance with the GCMS analysis. The authors gratefully acknowledge Mr. Usman and Miss Aaiinaa's assistance in crushing some samples, and Dr. Ibraki's assistance in digesting the ICP-MS samples. The authors would like to thank the editor and anonymous reviewers for providing constructive feedback on an earlier version of the work, which helped to improve it significantly.
\end{abstract}

Author contributions NAY involved in conceptualization; methodology; formal analysis; investigation; funding acquisition; and writing-original manuscript; KAM involved in conceptualization; resources; supervision; and writing-review and editing; MO involved in resources; supervision; and writing-review and editing; AAA involved in investigation.

Funding The authors declare the following financial interests/personal relationships which may be considered as potential competing interests: Award of $\mathrm{PhD}$ scholarship to the first author by Usmanu Danfodiyo University Sokoto through Tertiary Education Trust Fund, Award of research grants by the University of Malaya (GPF019B-2018; IF064-2019).

\section{Declarations}

Conflict of interest The authors declare that they have no known competing financial interests or personal relationships that could have appeared to influence the work reported in this paper.

Open Access This article is licensed under a Creative Commons Attribution 4.0 International License, which permits use, sharing, adaptation, distribution and reproduction in any medium or format, as long as you give appropriate credit to the original author(s) and the source, provide a link to the Creative Commons licence, and indicate if changes were made. The images or other third party material in this article are included in the article's Creative Commons licence, unless indicated otherwise in a credit line to the material. If material is not included in the article's Creative Commons licence and your intended use is not permitted by statutory regulation or exceeds the permitted use, you will need to obtain permission directly from the copyright holder. To view a copy of this licence, visit http://creativecommons.org/licenses/by/4.0/.

\section{References}

Abubakar U, Usman MB, Aliyuda K, Dalha A, Bello AM, Linus LN (2021) Major and trace element geochemistry of the shales of Sekuliye Formation, Yola Sub-Basin, Northern Benue Trough, Nigeria: implications for provenance, weathering intensity, and tectonic setting. J Sediment Environ. https://doi.org/10.1007/ s43217-021-00067-2

Abubakar U, Usman MB, Bello AM, Garba TA, Hassan S (2019) Geochemical and palaeocurrent analysis of the Tertiary Kerri-Kerri Formation in the Gongola Sub-Basin of the Northern Benue Trough North-eastern Nigeria: implications for provenance, tectonic setting and palaeoweathering. SN Appl Sci 1(10):1-11. https://doi.org/10.1007/s42452-019-1196-7

Adebanji KA, Sarki Yandoka BM, AbdullahAkaegbobi WHIM (2015) Molecular geochemical evaluation of late cretaceous sediments from chad (bornu) basin, NE Nigeria: implications for paleodepositional conditions, source input and thermal maturation. Arab J Geosci 8:1591-1609. https://doi.org/10.1007/s12517-014-1341-y

Adebanji KA, Abdullah WH, Hakimi MH, Babangida MSY, Mustapha KA, Adeyinka OA (2014) Trace elements geochemistry of kerogen in upper cretaceous sediments, Chad (Bornu) Basin, northeastern Nigeria: origin and paleo-redox conditions. J Afr Earth Sc. https://doi.org/10.1016/j.jafrearsci.2014.08.014

Adekola SA, Akinlua A, Mangelsdorf K (2012) Organic geochemical evaluation of cretaceous shale samples from the orange Basin, South Africa. Appl Geochem 27:1633-1642. https://doi.org/10. 1016/j.apgeochem.2012.03.012

Ahmad I, Chandra R (2013) Geochemistry of loess-paleosol sediments of Kashmir Valley, India: provenance and weathering. J Asian Earth Sci 66:73-89. https://doi.org/10.1016/j.jseaes.2012.12.029

Akinlua A, Adekola SA, Adeyemi AK (2018) Rare earth and trace element geochemistry of Cretaceous kerogens. Arab J Geosci. https://doi.org/10.1007/s12517-018-3900-0

Akinlua A, Olise FS, Akomolafe AO, McCrindle RI (2016) Rare earth element geochemistry of petroleum source rocks from northwestern Niger Delta. Mar Pet Geol. https://doi.org/10.1016/j.marpe tgeo.2016.06.023

Akinlua A, Sigedle A, Buthelezi T, Fadipe OA (2015) Trace element geochemistry of crude oils and condensates from South African Basins. Mar Pet Geol 59:286-293. https://doi.org/10.1016/j. marpetgeo.2014.07.023

Akinlua A, Maende A, Adekola SA, Swakamisa O, Fadipe OA, Akinyemi SA (2011) Source rock potential of selected Cretaceous shales, orange Basin, South Africa. Int Geol Rev 53:1508-1521. https://doi.org/10.1080/00206811003755370

Akinlua A, Adekola SA, Swakamisa O, Fadipe OA, Akinyemi SA (2010) Trace element characterisation of cretaceous orange Basin hydrocarbon source rocks. Appl Geochem 25(10):1587-1595. https://doi.org/10.1016/j.apgeochem.2010.08.008

Akinlua A, Ajayi TR, Adeleke BB (2007a) Organic and inorganic geochemistry of Northwestern Niger Delta. Geochem J 41:271-281. https://doi.org/10.2343/geochemj.41.271

Akinlua A, Torto N, Ajayi TR, Oyekunle JAO (2007b) Trace metals characterisation of Niger Delta kerogens. Fuel 86:1358-1364. https://doi.org/10.1016/j.fuel.2006.11.004

Al-Khafaji AJ, Hakimi MH, Mohialdeen IMJ, Idan RM, Afify WE, Lashin AA (2020) Geochemical characteristics of crude oils and basin modelling of the probable source rocks in the Southern Mesopotamian Basin, South Iraq". J Petrol Sci Eng. https://doi. org/10.1016/j.petrol.2020.107641

Andersson RA, Kuhry P, Meyers P, Zebühr Y, Crill P, Mörth M (2011) Impacts of paleohydrological changes on n-alkane biomarker compositions of a holocene peat sequence in the eastern European Russian Arctic. Org Geochem 42:1065-1107. https://doi. org/10.1016/j.orggeochem.2011.06.020

Andersson POD, Worden RH, Hodgson DM, Flint S (2004) Provenance evolution and chemostratigraphy of a palaeozoic submarine fancomplex: tanqua karoo basin, South Africa. Mar Petrol Geol 21:555-577. https://doi.org/10.1016/j.marpetgeo.2004.01.004 
Aquino Neto FR, Triguis J, Azevedo DA, Rodrigues R, Simoneit BRT (1989) Organic geochemistry of geographically unrelated Tasmanites. Org Geochem 18(6):791-803. https://doi.org/10.1016/ 0146-6380(92)90048-3

Armstrong-Altrin JS (2009) Provenance of sands from cazones, acapulco, and bahía kino beaches, México. Rev. Mex. Ciencias Geol 26 764-782. http://www.scielo.org.mx/scielo.php?script=sci_ arttext\&pid=S1026-87742006000300012

Ayinla HA, Abdullah WH, Makeen YM, Abubakar MB, Jauro A, Sarki Yandoka BM, Zainal Abidin NS (2017) Petrographic and geochemical characterization of the upper cretaceous coal and mudstones of gombe formation, gongola sub-basin, Northern Benue Trough Nigeria: Implication for organic matter preservation, paleodepositional environment and tectonic settings. Int $\mathbf{J}$ Coal Geol 180:67-82. https://doi.org/10.1016/j.coal.2017.06.010

Barton KR, Muntingh A, Noble RDP (1993) Geophysical and Geological studies applied to hydrocarbon exploration on the West Coast Margin of South Africa. Extended abstract of the Third International Congress of the Brazilian Geophysical Society, Rio de Janeiro, Brazil.7-11 1993. Doi: https://doi.org/10.3997/22144609-pdb.324.1316

Barwise AJG (1990) Role of nickel and vanadium in petroleum classification. Energy Fuels 4:647-652. https://doi.org/10.1021/ef000 $24 \mathrm{a} 005$

Bechtel A, Jia JL, Strobl SA, Sachsenhofer RF, Liu ZJ, Gratzer R, Püttmann W (2012) Palaeoenvironmental conditions during deposition of the Upper Cretaceous oil shale sequences in the Songliao Basin (NE China): Implications from geochemical analysis. Org Geochem 46:76-95. https://doi.org/10.1016/j.orggeochem.2012. 02.003

Bechtel A, Gruber W, Sachsenhofer RF, Gratzer R, Püttmann W (2001) Organic geochemical and stable carbon isotopic investigation of coals formed in low-lying and raised mires within the Eastern Alps (Austria). Org Geochem 32(682):1289-1310. https://doi. org/10.1016/S0146-6380(01)00101-2

Bessa AZE, Armstrong-Altrin JS, Fuh GC, Betsi TB, Kelepile T, Ndjigui PD (2021) Mineralogy and geochemistry of the Ngaoundaba Crater Lake sediments, northern Cameroon: implications for provenance and trace metals status. Acta Geochimica. https:// doi.org/10.1007/s11631-021-00463-5

Broad D, Jungslager E, McLachlan I, Roux J (2006) Offshore Mesozoic basins. The Geology of South Africa. Geological Society of South Africa, Johannesburg Council for Geoscience, Pretoria, $553-571$

Brown LF (1995) Sequence Stratigraphy in Offshore South African Divergent Basins: An Atlas on Exploration for Cretaceous Lowstand Traps by Soekor (Pty) Ltd, AAPG Studies in Geology 41: AAPG

Budzinski H, Garrigues PH, Connan J, Devillers J, Domine D, Radke M et al (1995) Alkylated phenanthrene distributions as maturity and origin indicators in crude oils and rock extracts. Geochim Cosmochim Acta 59:2043-2056

Calder JH (1993) The evolution of a ground-water-influenced (Westphalian B) peat-forming ecosystem in a piedmont setting: The No. 3 Seam, Springhill Coalfield, Cumberland Basin, Nova Scotia. In: Cobb, J.C., Cecil, C.B. (Eds.), Modern and Ancient CoalForming Environments, Geological Society of America Special Paper 286, 153-181

Calder JH, Gibling MR, Mukhopadhyay PK (1991) Peat formation in a Westphalian B piedmont setting, cumberland basin, nova scotia: implications for the maceral-based interpretation of rheotrophic and raised paleomires. Bulletin De La Société Géologique De France 162:283-298

Calvert SE, Bustin RM, Ingall ED (1996) Influence of water column anoxia and sediment supply on the burial and preservation of organic carbon in marine shales. Geochim Cosmochim Acta 60:1577-1593

Cao J, Wu M, Chen Y, Hu K, Bian L, Wang L, et al (2012) Trace and rare earth element geochemistry of Jurassic mudstones in the northern Qaidam Basin, northwest China 72 245-252

Chen Z, Simoneit BRT, Wang TG, Ni Z, Yuan G, Chang X (2018) Molecular markers, carbon isotopes, and rare earth elements of highly mature reservoir pyrobitumens from Sichuan Basin, southwestern China: Implications for Precambrian-Lower Cambrian petroleum systems. Precambr Res 317:33-35. https://doi. org/10.1016/j.precamres.2018.08.005

Collister JW, Wavrek DA (1996) 13C compositions of saturate and aromatic fractions of lacustrine oils and bitumens: evidence for water column stratification. Org Geochem 24(8-9):913-920. https://doi.org/10.1016/S0146-6380(96)00066-6

Connan J, Bouroullec J, Dessort D, Albrecht P (1986) The microbial input from carbonate-anhydrite facies of a sabkha paleoenvironment from guatemala: a molecular approach. Org Geochem 10:29-50. https://doi.org/10.1016/0146-6380(86)90007-0

Connan J, Cassou AM (1980) Properties of gases and petroleum liquids derived from terrestrial kerogen at various maturation levels. Geochim Cosmochim Acta 44:1-23. https://doi.org/10.1016/ 0016-7037(80)90173-8

Cox R, Lowe DR, Cullers RL (1995) The influence of sediment recycling and basement composition on evolution of mudrock chemistry in the southwestern United States. Geochem Cosmochim Acta 59:2919-2940. https://doi.org/10.1016/0016-7037(95) 00185-9

Cumming VM, Selby D, Lillis PG, Lewan MD (2014) Re-Os geochronology and Os isotope fingerprinting of petroleum sourced from a Type I lacustrine kerogen: insights from the natural Green River petroleum system in the Uinta Basin and hydrous pyrolysis experiments. Geochim Cosmochim Acta 138:32-56. https://doi. org/10.1016/j.gca.2014.04.016

Davies JC (1970) Petrology of Cretaceous mowry shale of Wyoming Am. Assoc Petrol Geol Bull 54(3):487-502. https://doi.org/10. 1306/5D25C9B3-16C1-11D7-8645000102C1865D

Davies CPN (1997) Unusual biomarker maturation ratio changes through the oil window, a consequence of varied thermal history. Org Geochem 27:537-560. https://doi.org/10.1016/S01466380(97)00059-4

Deng HW, Qian K (1993) Analysis on sedimentary geochemistry and environment. Science Technology Press, Gansu, pp 15-85 (in Chinese)

Ding W, Li C, Li C, Xu C, Jiu K, Zeng W et al (2012) Fracture development in shale and its relationship to gas accumulation. Geosci Front 3(1):97-105. https://doi.org/10.1016/j.gsf.2011.10.001

Escobar M, Márquez G, Inciarte S, Rojas J, Esteves I, Malandrino G (2011) The organic geochemistry of oil seeps from the Sierra de Perijá eastern foothills, Lake Maracaibo Basin, Venezuela. Org Geochem 42:727-738. https://doi.org/10.1016/j.orggeochem. 2011.06.005

El Diasty WSh, El Beialy Y, Mahdi AQ, Peters KE (2016) Geochemical characterization of source rocks and oils from northern Iraq: Insights from biomarker and stable carbon isotope investigations. Mar Pet Geol 207:1140-1162. https://doi.org/10.1016/j.marpe tgeo.2016.07.019

Ficken KJ, Li B, Swain DL, Eglinton G (2000) An n-alkane proxy for the sedimentary input of submerged/floating freshwater aquatic macrophytes. Org Geochem 31(7-8):745-749. https://doi.org/ 10.1016/S0146-6380(00)00081-4

Frankenberger A, Brooks RR, Varela-Alvarez H, Collen JD, Filby RH, Fitzgerald SL (1994) Classification of some New Zealand crude oils and condensates by means of their trace element contents. Appl Geochem 9:65-71. https://doi.org/10.1016/0883-2927(94) 90053-1

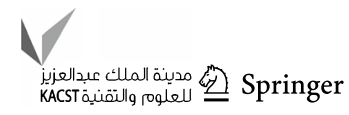


Fu X, Wang J, Zeng Y, Cheng J, Tano F (2011) Origin and mode of occurrence of trace elements in marine oil shale from the Shengli River Area, Northern Tibet. China Oil Shale 28(4):487-506. https://doi.org/10.3176/oil.2011.4.03

Galarraga F, Reategui K, Martïnez A, Martínez M, Llamas JF, Márquez $\mathrm{G}$ (2008) V/Ni ratio as a parameter in palaeoenvironmental characterization of non-mature medium-crude oils from several Latin American basins. J Petrol Sci Eng 61:9-14. https://doi.org/10. 1016/j.petrol.2007.10.001

Garcia D, Fonteilles M, Moutte J (1994) Sedimentary fractionations between $\mathrm{Al}, \mathrm{Ti}$, and $\mathrm{Zr}$ and the genesis of strongly peraluminous granites. J Geol 102:411-422

Genik GJ (1992) Regional framework, structural and petroleum aspects of rift basins in Niger, Chad and the Central African Republic (C.A.R.). Tectonophysics 213:169-185. https://doi.org/10.1016/ 0040-1951(92)90257-7

Gerrard I, Smith G (1982) Post Paleozoic succession and structure of the southwestern African continental margin: studies in continental margin geology: American Association of Petroleum Geologists Memoir 34: Studies in Continental Margin Geology. Pub. Id: A110 (1982), pp. 49-74

Gogoi M, Mathur N, Kumar TS, Wailing T, Pukan S (2021) Geochemical characterization of shales of the Eocene Disang Group Kohima Syncline India: Inferences to hydrocarbon potential and depositional environment. Pet Res 6(1):42-56. https://doi.org/10. 1016/j.ptlrs.2020.09.001

Guiraud R, Maurin JC (1992) Early cretaceous rifts of Western and Central Africa: an overview. Tectonophysics 213:153-168. https://doi.org/10.1016/0040-1951(92)90256-6

Gürgey K (1999) Geochemical characteristics and thermal maturity of oils from the thrace basin (western Turkey) and western Turkmenistan. J Pet Geol 22:167-189. https://doi.org/10.1111/j.17475457.1999.tb00466.x

Hakimi MH, Mohialdeen IMJ, Abdullah WH, Wimbledon W, Makeen YM, Mustapha KA (2015) Biomarkers and inorganic geochemical elements of late jurassic-early cretaceous limestone sediments from banik village in the Kurdistan Region, Northern Iraq: implications for origin of organic matter and depositional environment conditions. Arab J Geosci 8:9407-9421. https://doi.org/10.1007/ s12517-015-1863-y

Han S, Zhang Y, Huang J, Rui Y, Tang Z (2020) Elemental geochemical characterization of sedimentary conditions and organic matter enrichment for lower cambrian shale formations in northern guizhou, south china. Minerals 10:1-21. https://doi.org/10.3390/ $\min 10090793$

Hartwig A, Anka Z, di Primio R (2012) Evidence of a widespread paleo-pockmarked field in the Orange Basin: an indication of an early Eocene massive fluid escape event offshore South Africa. Mar Geol 332:222-234. https://doi.org/10.1016/j.margeo.2012. 07.012

Hayashi KI, Fujisawa H, Holland HD, Ohmoto H (1997) Geochemistry of $\sim 1.9 \mathrm{Ga}$ sedimentary rocks from northeastern labrador. Canada Geochem Cosmochim Acta 61:4115-4137. https://doi. org/10.1016/S0016-7037(97)00214-7

He D, Huang H, Arismendi GG (2019) n-Alkane distribution in ombrotrophic peatlands from the northeastern Alberta, Canada, and its paleoclimatic implications. Palaeogeogr Palaeoclimatol Palaeoecol 528:247-257. https://doi.org/10.1016/j.palaeo.2019.05.018

Hentschel A, Esterle JS, Golding S (2016) The use of stable carbon isotope trends as a correlation tool: an example from the Surat Basin, Australia. The APPEA Journal 56:355-368. https://doi. org/10.1071/AJ15026

Herbin JP, Muller C, de Graciansky PC, Jacquin T, Magniez-Jannin F, Unternehr P, Dias-Brito D (1987) Cretaceous anoxic events in the South Atlantic. Rev Brasil Geocienc 17(2):92-99
Hernández-Hinojosa V, Montiel-García P, Armstrong-Altrin J, Nagarajan R, Kasper-Zubillaga J (2018) Textural and geochemical characteristics of beach sands along the western Gulf of Mexico, Mexico. Carpath J Earth Environ Sci 13:161-174

Herron MM (1988) Geochemical classification of terrigenous sands and shales from core or log data. J Sediment Petrol 58:820-829. https://doi.org/10.1306/212F8E77-2B24-11D7-8648000102 C1865D

Hirsch KK, Bauer K, Scheck-Wenderoth M (2009) Deep structure of the western South African passive margin - Results of a combined approach of seismic, gravity and isostatic investigations. Tectonophysics 470(1-2):57-70. https://doi.org/10.1016/j.tecto. 2008.04.028

Hirsch KK, Scheck-Wenderoth M, Paton DA, Bauer K (2007) Crustal structure beneath the Orange Basin, South Africa. S Afr J Geol 110(2-3):249-260. https://doi.org/10.2113/gssajg.110.2-3.249

Hossain ZM, Sampei Y, Roser BP (2009) Characterization of organic matter and depositional environment of Tertiary mudstones from the Sylhet Basin, Bangladesh. Org Geochem 40:743-754. https:// doi.org/10.1016/j.orggeochem.2009.04.009

Huang WY, Meinschein WG (1979) Sterols as ecological indicators. Geochim Cosmochim Acta 43:739-745. https://doi.org/ 10.1016/0016-7037(79)90257-6

Hughes WB, Holba AG, Dzou LIP (1995) The ratios of dibenzothiophene to phenanthrene and pristane to phytane as indicators of depositional environment and lithology of petroleum source rocks. Geochim Cosmochim Acta 59:3581-3598. https://doi. org/10.1016/0016-7037(95)00225-O

Ingall E, Jahnke R (1994) Evidence for enhanced phosphorus regeneration from marine sediments overlain by oxygen depleted waters. Geochim Cosmochim Acta 58:2571-2575. https://doi. org/10.1016/0016-7037(94)90033-7

Jarvie DM (2012) Shale resource systems for oil and gas: Part 1shale gas resource systems. In: Breyer, J.A. (Ed.), Shale Reservoirs e Giant Resources for the 21st Century: the American Association of Petroleum Geologists, vol. 97, pp. 69-87

Jia J, Bechtel A, Liu Z, Susanne AI, Strobl PS, Reinhard FS (2013) Oil shale formation in the upper cretaceous Nenjiang formation of the songliao basin (NE China): implications from organic and inorganic geochemical analyses. Int J Coal Geol 113:1126. https://doi.org/10.1016/j.coal.2013.03.004

Jingjing L, Shifeng D, James CH, Tim AM, Ofentse MM, Victor PN, Tatiana IP, David F, Graham Ian T, Xiaolin S (2020) Stable isotopes of organic carbon, palynology, and petrography of a thick low-rank Miocene coal within the Mile Basin, Yunnan Province, China: implications for palaeoclimate and sedimentary conditions. Org Geochem. https://doi.org/10.1016/j.orgge ochem.2020.104103

Jungslager EH (1999) Petroleum habitats of the Atlantic margin of South Africa. Geolo Soc, London, Spec Pub 153(1):153-168. https://doi.org/10.1144/GSL.SP.1999.153.01.10

Kruge MA, Hubert JF, Akes RJ, Meriney PE (1990) Biological markers in Lower Jurassic synrift lacustrine black shales, Hartford Basin, Connecticut, U.S.A. Org Geochem 15:281-289. https:// doi.org/10.1016/0146-6380(90)90006-L

Kuhlmann G, Adams S, Campher C, van der Spuy D, di Primio R, Horsfield B (2010) Passive margin evolution and its controls on natural gas leakage in the southern Orange Basin, blocks 3/4, offshore South Africa. Mar Pet Geol 27(4):973-992. https:// doi.org/10.1016/j.marpetgeo.2010.01.010

Lewan MD (1984) Factors controlling the proportionality of vanadium to nickel in crude oils. Geochim Cosmochim Acta 48:2231-2238. https://doi.org/10.1016/0016-7037(84)90219-9

Li Q, Wu S, Xia D, You X, Zhang H, Lu H (2020) Major and trace element geochemistry of the lacustrine organic-rich shales from the Upper Triassic Chang 7 Member in the southwestern 
Ordos Basin, China: Implications for paleoenvironment and organic matter accumulation. Mar Pet Geol 111:852-867. https://doi.org/10.1016/j.marpetgeo.2019.09.003

Liang C, Wu J, Jiang Z, Cao Y, Song G (2018) Sedimentary environmental controls on petrology and organic matter accumulation in the upper fourth member of the Shahejie Formation (Paleogene, Dongying depression, Bohai Bay Basin, China). Int J Coal Geol 186:1-13. https://doi.org/10.1016/j.coal.2017. 11.016

Lijmbach GW (1975) On the origin of petroleum: Paper presented at the 9th World petroleum Congress, Tokyo, Japan, May 1975. https://onepetro.org/WPCONGRESS/Proceedings-abstract/ WPC09/All-WPC09/WPC-16134/199233

Liu YJ, Cao LM, Li ZL, Wang HN, Chu TQ, Zhang JR (1984) Element geochemistry. Science Press, Beijing, pp 283-372 (in Chinese). https://doi.org/10.1007/s00531-013-0903-7

Liu G, Zhou D (2007) Application of microelements analysis in identifying sedimentary environment taking Qianjiang Formation in the Jiang Han Basin as an example. Pet Geol Exp 29(307310):314 (in Chinese with English abstract)

Long H, Flemings PB, Germaine JT, Saffer DM (2011) Consolidation and overpressure near the seafloor in the Ursa Basin, Deepwater Gulf of Mexico. Earth Planet Sci Lett 305(1-2):1035-1049. https://doi.org/10.1016/j.eps1.2011.02.007

López-Días V, Urbanczyk J, Blanco CG, Borrego AG (2013) Biomarkers as paleoclimate proxies in peatlands in coastal high plains in Asturias. N Spain Int J Coal Geol 116-117:270-280. https://doi. org/10.1016/j.coal.2013.04.006

Mackenzie AS, Patience RL, Maxwell JR, Vandenbroucke M, Durand B (1980) Molecular parameters of maturation in the Toarcian shales, Paris Basin, France-I. Changes in the configurations of acyclic isoprenoid alkanes, steranes, and triterpanes. Geochim Cosmochim Acta 44:1709-1721. https://www.sciencedirect.com/ science/article/abs/pii/0016703780902227

Maffei M (1996) Chemotaxonomic significance of leaf wax n-alkanes in the Umbelliferae, Cruciferae and Leguminosae (Subf. Papilionoideae). Biochemical Systematics and Ecology 24, 531-545. http://www.sciencedirect.com/science/article/pii/0305197896 000373

Makeen YM, Abdullah WH, Hakimi MH, Hadad YT, Elhassan OMA, Mustapha A (2015) Geochemical characteristics of crude oils, their asphaltene and related organic matter source inputs from Fula oilfields in the Muglad Basin Sudan. Marine Pet Geol 67:816-828. https://doi.org/10.1016/j.marpetgeo.2015.07.001

Makeen YM, Abdullah WH, Hakimi MH (2015a) The origin, type and preservation of organic matter of the Barremian-Aptian organicrich shales in the Muglad Basin, Southern Sudan, and their relation to paleoenvironmental and paleoclimate conditions. Marine and Petroleum Geology 65, 187-197. https://www.sciencedirect. com/science/article/pii/S0264817215000823

Marynowsky L, Narkiewicz M, Grelowski C (2000) Biomarkers as environmental indicators in a carbonate complex, example from the middle to upper devonian, holy cross mountains, Poland. Sediment Geol 137:187-212. https://doi.org/10.1016/S00370738(00)00157-3

McLennan SM, Hemming S, McDaniel DK, Hanson GN (1993) Geochemical approaches to sedimentation, provenance, and tectonics. In: In: Johnsson, M.J., Basu, A. (Eds.), Processes Controlling the Composition of Clastic Sediments: Geological Society of America Special Paper, vol. 284. pp. 21-40

McManus J, Berelson WM, Hammond DE, Klinkhammer GP (1999) Barium cycling in the North Pacific: implication for the utility of $\mathrm{Ba}$ as a paleoproductivity and paleoalkalinity proxy. Paleoceanogr Paleoclimatol 14:53-61. https://doi.org/10.1029/1998P A900007
McMillan IK (2003) Foraminiferally defined bilostratigraphic episodes and sedimentation pattern of the Cretaceous drift succession (Early Barremian to Late Maastrichtian) in seven basins on the South African and southern Namibian continental margin. South African Journal of Science, 99(11-12), 537-576. https:// hdl.handle.net/10520/EJC97566

Meyers PA, Snowdon LR (1993) Types and maturity of organic matter accumulated during Early Cretaceous subsidence of the Exmouth Plateau, Northwest Australia margin. AAPG Stud Geol 37:119-130. SG 37: Source Rocks in a Sequence Stratigraphic Framework. Pub. Id: A033 (1993), 119- 130

Mohialdeen IMJ, Raza SM (2013) Inorganic geochemical evidence for the depositional facies associations of the Upper Jurassic Chia Gara Formation in NE Iraq. Arab J Geosci 6:4755-4770. https:// doi.org/10.1007/s12517-012-0716-1

Moldowan JM, Peters KE, Carlson RMK, Schoell M, Abu-Ali MA (1994) Di verse applications of petroleum biomarker maturity parameters. Arab J Sci Eng 19:273-298

Moosavirada SM, Janardhanab MR, Sethumadhava MS, Moghadam MR, Shankara M (2011) Geochemistry of lower jurassic shales of the shemshak formation, kerman province, central Iran: provenance, source weathering and tectonic setting. Geochemistry 71:279-288. https://doi.org/10.1016/j.chemer.2010.10.001

Moradi AV, Sarı A, Akkaya P (2016) Geochemistry of the Miocene oil shale (Hançili Formation) in the Çankırı-Çorum basin, central Turkey: Implications for paleoclimate conditions, source-area weathering, provenance and tectonic setting. Sed Geol 341:289303. https://doi.org/10.1016/j.sedgeo.2016.05.002

Muntingh A (1993) Geology, Prospects in Orange Basin Offshore Western South-Africa. Oil \& Gas Journal, 91(4), 106-109. https://www.ogj.com/home/article/17223488/geology-prosp ects-in-orange-basin-offshore-western-south-africa

Muntingh A, Brown JrL (1993) Sequence Stratigraphy of Petroleum Plays, Post-Rift Cretaceous Rocks (Lower Aptian to Upper Maastrichtian), Orange Basin, Western Offshore, South Africa: Chapter 4: Siliciclastic Sequence Stratigraphy: Recent Developments and Weimer P, Posamentier H (1993), 71-98

Nagarajan R, Armstrong-Altrin JS, Kessler FL, Jong J (2017) Petrological and geochemical constraints on provenance, paleoweathering, and tectonic setting of clastic sediments from the Neogene Lambir and Sibuti Formations, northwest Borneo. In Sediment provenance (pp. 123-153). https://www.sciencedirect.com/scien ce/article/pii/B9780128033869000071

Nesbitt HW, Young GM (1982) Early Proterozoic climates and plate motions inferred from major element chemistry of lutites. Nature 299:715-717. https://doi.org/10.1038/299715a0

Ortiz JE, Torres T, Delgado A, Llamas JF, Soler V, Valle M et al (2010) Palaeoenvironmental changes in the padul basin (Granada, Spain) over the last $1 \mathrm{Ma}$ based on the biomarker content. Palaeogeogr Palaeoclimatol Palaeoecol 298:286-299. https://doi. org/10.1016/j.palaeo.2010.10.003

Ortiz JE, Moreno L, Torres T, Vegas J, Ruiz-Zapata B, García-Cortés Á et al (2013) A 220 ka palaeo-environmental reconstruction of the Fuentillejo maar lake record (Central Spain) using biomarker analysis. Org Geochem 55:85-97. https://doi.org/10.1016/j.orgge ochem.2012.11.012

PASA (2003) Exploration Opportunities in the Deepwater Orange Basin, off the West Coast of South Africa. https://petroleuma gencysa.com/ (accessed 07.09.10)

Paton DA, di Primio R, Kuhlmann G, van der Spuy D, Horsfield B (2007) Insights into the petroleum system evolution of the southern orange basin, South Africa. S Afr J Geol 110(2-3):261-274. https://doi.org/10.2113/gssajg.110.2-3.261

Paton DA, Van der Spuy D, di Primio R, Horsfield B (2008) Tectonically induced adjustment of passive-margin accommodation space; influence on the hydrocarbon potential of the Orange

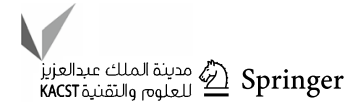


Basin. South Africa AAPG Bulletin 92(5):589-609. https://doi. org/10.1306/12280707023

Peters KE, Moldowan JM (1993) The biomarker guide: interpreting molecular fossils in petroleum and ancient sediments. PrenticeHall Inc, Englewood Cliffs, New Jersey

Peters KE, Walters CC, Moldowan JM (2005) The biomarker guide: biomarkers and isotopes in petroleum exploration and earth history, 2nd edn. Cambridge University Press, Cambridge

Pi DH, Cong-Qiang L, Shields-Zhoud AG, Shao-Yong J (2013) Trace and rare earth element geochemistry of black shale and kerogen in the early cambrian niutitang formation in Guizhou province, South China: constraints for redox environments and origin of metal enrichments. Precambr Res 225:218-229. https://doi.org/ 10.1016/j.precamres.2011.07.004

Qiu XW, Liu CY, Wang FF, Deng Y, Mao GZ (2015) Trace and rare earth element geochemistry of the upper Triassic mudstones in the southern Ordos Basin, Central China. Geol J 50:399-413. https://doi.org/10.1002/gj.2542

Qiuhua Y, Zhigang YT (2011) Geochemical characteristics of ordovician crude oils in the northwest of the Tahe oil field, Tarim Basin. Chin J Geochem 30:93-98. https://doi.org/10.1007/ s11631-011-0489-3

Radke M, Vriend SP, Ramanampisoa LR (2000) Alkyldibenzofurans in terrestrial rocks: influence of organic facies and maturation. Geochim Cosmochim 64:275-286. https://doi.org/10.1016/ S0016-7037(99)00287-2

Radke M, Welte DH (1983) The methylphenanthrene index (MPI): a maturity parameter based on aromatic hydrocarbons. In: Bjorøy M et al (eds) Advances in Organic Geochemistry, 1981. John Wiley and Sons Inc, Chichester, pp 504-512

Radke M, Welte DH, Willsch H (1982) Geochemical study on a well in the Western Canada Basin: relation of the aromatic distribution pattern to maturity of organic matter. Geochim Cosmochim Acta 46:1-10. https://doi.org/10.1016/0016-7037(82) 90285-X

Roser BP, Korsch RJ (1988) Provenance signatures of sandstone-mudstone suites determined using discriminant function analysis of major-element data. Chem Geol 67:119-139. https://doi.org/10. 1016/0009-2541(88)90010-1

Roser BP, Korsch RJ (1986) Determination of tectonic setting of sandstone mudstone suites using $\mathrm{SiO}_{2}$ content and $\mathrm{K}_{2} \mathrm{O} / \mathrm{Na}_{2} \mathrm{O}$ ratio. J Geol 94:635-650

Ross DJK, Bustin RM (2009) Investigating the use of sedimentary geochemical proxies for palaeoenvironment interpretation of thermally mature organic-rich strata: examples from the Devonian- Mississippian shales, Western Canadian Sedimentary Basin. Chem Geol 260:1-19. https://doi.org/10.1016/j.chemg eo.2008.10.027

Roy DK, Roser BP (2013) Climatic control on the composition of Carboniferous-Permian Gondwana sediments, Khalaspir basin, Bangladesh. Gondwana Res 23:1163-1171. https://doi.org/10. 1016/j.gr.2012.07.006

Schwark L, Zink K, Lechtenbeck J (2002) Reconstruction of postglacial to early Holocene vegetation history in terrestrial Central Europe via cuticular lipid biomarkers and pollen records from lake sediments. Geology 30:463-466. https://doi.org/10.1130/ 0091-7613(2002)030\%3c0463:ROPTEH\%3e2.0.CO;2

Seifert WK, Moldowan JM (1978) Applications of steranes, terpanes and monoaromatics to the maturation, migration and source of crude oils. Geochim Cosmochim Acta 42:77-95. https://doi.org/ 10.1016/0016-7037(78)90219-3

Seifert WK, Moldowan JM (1986) Use of biological markers in petroleum exploration. In: Johns RB. Editor. vol. 24. Amsterdam: Methods in Geochemistry and Geophysics Book Series, p. 261. ®290
Shu T, Dazhen T, Hao X, Jianlong L, Xuefeng S (2013) Organic geochemistry and elements distribution in Dahuangshan oil shale, Southern Junggar Basin: origin of organic matter and depositional environment. Int J Coal Geol 115:41-51. https://doi.org/ 10.1016/j.coal.2013.05.004

Sinninghe Damsté JS, Kenig F, Koopmans MP, Koster J, Schouten S, Hayes JM, de Leeuw JW (1995) Evidence for gammacerane as an indicator of water column stratification. Geochim Cosmochim Acta 59:1895-1900. https://doi.org/10.1016/0016-7037(95) 00073-9

Sofer Z (1984) Stable carbon isotope compositions of crude oils: application to source depositional environments and petroleum alteration. Am Asso Petrol Geol Bull 68:31-49. https://doi.org/ 10.1306/AD460963-16F7-11D7-8645000102C1865D

Sofer Z (1980) Preparation of carbon isotopes for stable carbon isotope analysis of petroleum fractions. Anal Chem 52:1389-1391. https://doi.org/10.1021/ac50058a063

Sonfack AN, Ngueutchoua G, Kontchipe YSN, Sopie FT, Nkouathio DG, Wouatong ASL et al (2021) Mineralogical and geochemical signatures of surface stream sediments from Dibamba River basin, SW Cameroon: Implications for provenance, weathering, and tectonic setting. J Afr Earth Sc 181:104251. https://doi.org/ 10.1016/j.jafrearsci.2021.104251

Swaine DJ (1990) Trace elements in coal. Butterworths, London

Taohua H, Shuangfang L, Wenhao L, Zhaozhao T, Xinwen Z (2018) Effect of salinity on source rock formation and its control on the oil content in shales in the hetaoyuan formation from the biyang depression, Nanxiang Basin, Central China". Energy Fuels. https://doi.org/10.1021/acs.energyfuels.8b01075

Ten Haven HL, De Leeuw JW, Rullkötter J, Sinninghe Damsté JS, Scheck PA, Palmer SE, Zumberge JE, et al (1988) Application of biological markers in the recognition of palaeohypersaline environments. In: Fleet AJ, Kelts K, Talbot MR (eds) Lacustrine Petroleum Source Rocks. Geological Society Special Publication 40. Blackwell, London, pp 123-130. https://doi.org/10.1144/ GSL.SP.1988.040.01.11

Thornton SF, McManus J (1994) Application of organic carbon and nitrogen stable isotope and $\mathrm{C} / \mathrm{N}$ ratios as source indicators of organic matter provenance in estuarine systems: evidence from the Tay Estuary, Scotland. Estuar Coast Shelf Sci 38:219-233. https://doi.org/10.1006/ecss.1994.1015

Tissot BT, Welte DH (1984) Petroleum Formation and Occurrences, 2nd edn. Springer-Verlag, Berlin

Tribovillard N, Ramdani A, Trentesaux A (2005) Controls on organic accumulation in Late Jurassic shales of northwestern Europe as inferred from trace-metal geochemistry. In: N. Harris (Eds.), The Deposition of Organic Carbon-Rich Sediments: Models, Mechanisms, and Consequences. SEPM Special Publication 821 45-164. https://doi.org/10.2113/175.5.491

Van Aarssen BGK, Bastow TP, Alexander R, Kagi RI (1999) Distributions of methylated naphthalenes in crude oils: indicators of maturity, biodegradation and mixing. Org Geochem 30:12131227. https://doi.org/10.1016/S0146-6380(99)00097-2

Van Cappellen P, Ingall ED (1994) Benthic phosphorus regeneration, net primary production, and ocean anoxia: a model of the coupled marine biogeochemical cycles of carbon and phosphorus. Paleoceanography 9:677-692. https://doi.org/10.1029/94PA0 1455

Van der Spuy D, Jikelo NA, Ziegler T, Bowyer M (2003) Deepwater 2D data reveal Orange basin objectives off western South Africa. Oil Gas J 101(14):44-49

Vegas J, Ruiz-Zapata B, Ortiz JE, Galán L, Torres T, García-Cortés A et al (2010) Identification of arid phases during the last 50 kyr Cal BP from the Fuentillejo maar lacustrine record (Campo 
de Calatrava Volcanic Field, Spain). J Quat Sci 25:1051-1062. https://doi.org/10.1002/jqs.1262

Venkatesan MI (1989) Tetrahymanol: its widespread occurrence and geochemical significance. Geochim Cosmochim Acta 53:30953101. https://doi.org/10.1016/0016-7037(89)90190-7

Verma SP, Armstrong-Altrin JS (2013) New multi-dimensional diagrams for tectonic discrimination of siliciclastic sediments and their application to precambrian basins. Chem Geol 355:117133. https://doi.org/10.1016/j.sedgeo.2015.11.011

Volk H, George SC, Middleton H, Schofield S (2005) Geochemical comparison of fluid inclusion and present-day oil accumulations in the Papuan Foreland - evidence for previously unrecognized petroleum source rocks. Org Geochem 36:29-51. https://doi.org/ 10.1016/j.orggeochem.2004.07.018

Volkman JK (1986) A review of sterol biomarkers for marine and terrigenous organic matter. Org Geochem 9:83-89. https://www.scien cedirect.om/science/article/abs/pii/0146638086900896

Wang AH (1996) Discriminant effect of sedimentary environment by the $\mathrm{Sr} / \mathrm{Ba}$ ratio of different existing forms. Acta Sedimentol Sin 14:168-173

Waples DW, Machihara T (1991) Biomarkers for Geologists: a practical guide to the application of steranes and triterpanes in petroleum geology. American Association of Petroleum Geologists Methods in Exploration 9, Tulsa, Oklahoma

Wei W, Algeo TJ (2020) Elemental proxies for paleosalinity analysis of ancient shales and mudrocks. Geochim Cosmochim Acta 287:341-366. https://doi.org/10.1016/j.gca.2019.06.034
Xiujian D, Guangdi L, Ming Z, Changhai G, Zhilong H, Jiangxiu Q, Xuejun L, Pangen W, Zhelong C (2016) Geochemical characterization and depositional environment of source rocks of small fault basin in Erlian Basin, northern China. Mar Pet Geol. https:// doi.org/10.1016/j.marpetgeo.2015.11.006

Zheng Y, Zhou W, Meyers PA, Xie S (2007) Lipid biomarkers in the Zoigê- Hongyuan peat deposit: indicators of Holocene climate changes in West China. Org Geochem 38:1927-1940. https://doi. org/10.1016/j.orggeochem.2007.06.012

Zumberge JE (1984) Source rocks of the La Luna (Upper Cretaceous) in the Middle Magdalena Valley, Colombia. In: Palacas, J.G. (Ed.), Geochemistry and Source Rock Potential of Carbonate Rocks. American Association of Petroleum Geologists, Tulsa, OK, pp. 127-133

Zumberge JE (1987) Terpenoid biomarker distributions in low maturity crude oils. Org Geochem 11:479-496. https://doi.org/10.1016/ 0146-6380(87)90004-0

Zumberge JE, Russell JA, Reid SA (2005) Charging of Elk Hills reservoirs as determined by oil geochemistry. Am Asso Petrol Geol Bull 89:1347-1371. https://doi.org/10.1306/05100504003

Publisher's Note Springer Nature remains neutral with regard to jurisdictional claims in published maps and institutional affiliations. 